\title{
ACCOUNTABILITY BY DESIGN: MOVING PRIMARY CARE REFORM AHEAD IN ALBERTA
}

\author{
Dr. Shannon M. Spenceley, Cheryl Andres, Janet Lapins, \\ Dr. Robert Wedel, Dr. Tobias Gelber, L.M. Halma ${ }^{\dagger}$
}

\section{SUMMARY}

Health-care reform is perennially popular in Alberta, but reality doesn't match the rhetoric. Government has invested more than $\$ 700$ million in Primary Care Networks - with little beyond anecdotal evidence of the value achieved with this investment. As the province redirects primary care to Family Care Clinics, the authors assert that simply tinkering with one part of the system is not the answer: health care must change on a system-wide basis. Drawing on the experiences of frontline staff and a rich body of literature, the authors present their vision for integrated team-based primary care, designed to be accountable to meet the needs of populations. This will require governance that makes primary care the hub of the system, and brings together government and health-services leadership to support the integration of primary and specialty care. There are shared accountabilities for achieving primary care that exhibits the attributes of high performing primary care systems, and these exist at multiple levels, from individuals seeking primary care, up to and including government. The authors make these accountabilities explicit, and outline strategies to secure their achievement that include system redesign, service delivery redesign and payment reform. All of this demands whole-system reform focused on primary care, and it won't be easy. There are plenty of vested interests at stake, and a truly transformative vision requires buy-in at every level. However, Alberta's rapidly growing and aging population makes it more urgent than ever to realize such a vision. This paper offers guidelines to spark the fresh thinking required.

\footnotetext{
We declare that two of our six authors are physicians currently practicing in PCN clinics in southern Alberta; both of these physicians are faculty of Alberta AIM. One of these physicians, Dr. Wedel, also co-chairs Alberta AIM. We also felt it important to declare from the outset that the authors come from a particular shared history: involvement in primary care reform in the former Chinook Health Region. This former health region has received numerous acknowledgments for its record of leading-edge reform around integrated primary care - we believe the lessons we have learned are still relevant, and applicable anywhere in the province. We also wish to state that despite this shared history, we come from different professional backgrounds and bring different perspectives. We have done our best to acknowledge and balance our biases as a team, and challenged one another to rise above any entrenched position. We fully acknowledge and accept, however, that as much as we believe that our experiences might be useful sources of practical wisdom, those same experiences could be legitimately criticized as sources of bias
} 


\section{ACCOUNTABILITY BY DESIGN: MOVING PRIMARY CARE REFORM AHEAD IN ALBERTA}

The American writer Adam Hochschild tells us that, "Work is hard. Distractions are plentiful. And time is short." For us, this quote sums up where we are in relation to actually reforming (not just restructuring) the health-care system in Alberta. After more than a decade of hard work that has generated more heat than light, we believe we have arrived at a window of opportunity; we have the knowledge, the experience, and hopeful glimpses of a political will to reform health care in Alberta along the lines of other high-performing health-care systems - systems that emphasize a primary health-care approach, and place primary care at the hub of the system. The distractions? They still abound: contentious politics around funding and accountability mechanisms for health-care providers, health- system instability and continual restructuring, a growing sense of change fatigue, and professional tensions over turf, to name just a few.

As a province, we have invested heavily in a particular model of primary care, the Primary Care Network (PCN). Since the inception of the PCN initiative, we have spent more than $\$ 700$ million on this model of primary care, with little more than anecdotal evidence to assure us that we have obtained value for money. What is clear to us, however, is that the investment goes beyond money. With some seven years of well-intended effort, it is tempting to let attachment to the model eclipse the necessary focus on primary care within a primary health care-oriented system: it serves no one to let any model become a distraction from the real underlying goal. Even as Alberta Health advances a new model, the Family Care Clinic, we believe there is risk associated with approaching primary care reform in a way that invites PCNs and FCCs to exist in parallel, duplicate effort and ultimately compete with one another for resources. Ultimately, what is needed is system change - without that, even the most perfect model of primary care will fail to achieve its potential. It is our intent to add to the ongoing dialogue on primary care reform in Alberta, based on evidence and our collective experience. It is our hope that this discussion will shine some light on potential pitfalls, and suggest some ways to avoid them. In this paper, we will:

1. Review the primary care reform journey in Alberta in relation to what we believe has gone wrong, and share examples of what we believe has gone well.

2. Propose an evidence-informed vision and clear objectives for the organization and delivery of primary care as the hub of a whole system oriented around primary health care.

3. Synthesize evidence and experience to propose strategies based on system redesign and integration, service delivery redesign, and payment reform in order to achieve this vision.

4. Summarize key accountabilities in achieving the vision.

As Katz ${ }^{l}$ reminded us, progress requires the elucidation of specific factors at multiple levels, from the interface with patient care, up to and including the level of policy; our accountabilityfocused recommendations will reflect this imperative. We also leave some factors off the table in this discussion, not because they are insignificant, but because we had to draw the line somewhere. We acknowledge these gaps in our discussion: issues around the federal/provincial/ territorial jurisdictions in health care, fund-holding in primary care, the equitable distribution

I Katz, Allan, Richard H. Glazier, and Janani Vijayaraghavan (2009), "The Health and Economic Consequences of Achieving a High-Quality Primary Health-care System in Canada. Applying What Works in Canada: Closing the Gap." 
of primary care resources and the complexity of organizing health services for extremely remote populations. Even with these limitations, we believe that the thinking here has something to offer the general discussion of primary care reform in Alberta.

\section{BACKGROUND}

First, to set the stage we believe a few words of clarification are needed about the terminological tangle between primary health care and primary care. Primary health care (PHC) refers to an approach to health and a spectrum of services that extend beyond the traditional health-care system. It is big picture, and includes factors that go well beyond health services, such as income, education, culture, environment, lifestyle, and social inclusion. ${ }^{2}$ On the other hand, primary care is only one part (albeit a significant part) of the picture. ${ }^{3}$ Primary care focuses on health-care services, including health promotion, illness and injury prevention, and the diagnosis and treatment of illness and injury. ${ }^{4}$ Primary care is the first point of delivery of health services to meet the health-care needs of an identified population, and is focused on coordinating all health services and information around a unique patient or family. It is, or should be, the hub of the health-care system, and features care delivered by multidisciplinary teams committed to whole person-centeredness, comprehensiveness, continuity of care and relationship over time, and the active participation of patients, families and communities. ${ }^{5}$ In Alberta, primary care has been called a "home in the health-care system," where most, but not all health needs can be met; we agree. We also agree that it is important to consider primary health care as an overarching and appropriate approach for the whole of health care (and truly relevant to many policy domains like housing, urban planning, education, and finance), but we don't consider it useful to think of primary health care as a home in the health-care system. To do so sets up expectations that are unrealistic, and invites the kind of thinking that duplicates existing services and wastes resources. Primary care, as important as it is, cannot carry the mantle of primary health care by itself - it cannot be or do all things related to health. It can, however, be oriented towards, and embedded within, an overall primary health-care approach to health in the province, so primary care does have something to contribute to primary health care. To be able to do that however, we suggest that Alberta must proceed to design and deliver primary care services in ways that evidence and experience suggest will support good health outcomes, and commit to transforming Alberta's health system to one that is committed to the principles of primary health care, and oriented around a primary care hub.

\footnotetext{
2 “About Primary Health Care.” http://www.hc-sc.gc.ca/hcs-sss/prim/about-apropos-eng.php, accessed December 12, 2012.

3 Bhatia, Mirgesh and Susan Rifkin (2010). "A Renewed Focus on Primary Health Care: Revitalize or Reframe?” Global Health 6:13.

4 “About Primary Health Care.” op. cit.

5 Lerberghe, Wim Van et al. (2008) "Primary Health Care - Now More Than Ever."

6 Tholl, Bill and Kelly Grimes (2012). "Strengthening Primary Health Care in Alberta through Family Care Clinics: From Concept to Reality”p. ii.
} 


\section{THE JOURNEY IN ALBERTA}

The Alberta government committed to primary care reform eight years ago with the launch of the Local Primary Care Initiatives, later known as the Primary Care Networks (PCNs), in 2005. A tri-lateral agreement between the Alberta Medical Association (AMA), the Ministry of Health (AH), and the health authorities of Alberta was negotiated, and PCNs were established around the province as a series of joint ventures between local health authorities and primary care physician clinics. We found it useful to reflect on why this was the chosen direction, and on what we believe has been learned up to this point in the journey. The evidence eight years ago was becoming clearer that health systems with a strong primary care orientation were achieving better population health outcomes, more appropriate health service utilization, greater equity, better care continuity, higher user satisfaction, lower costs, and better chronic disease support and management. ${ }^{7}$ It was and is our belief that the overarching goal in Alberta at the time was to try and bring a primary care orientation to the health-care system by bringing primary care practices (which existed as largely separate islands of general practitioner offices) and the rest of the system together - something we saw as an appropriate, if narrowly conceived, motivation. Establishing the key players as the Alberta Medical Association, health authorities, and government had two immediate effects: embedding primary care reform into collective bargaining with physicians, and simultaneously sending a message to other providers that their contributions were somehow less essential. Although the first effect has since been addressed, the second will persist as long as we continue to fund primary care as a physician-only enterprise that views team-based care as an optional strategy. In fact, and notwithstanding the laser-like clarity of hindsight, we believe there is much to learn from the mistakes made over the course of primary care evolution in Alberta, and we summarize what we see as the key missteps in Table 1 . We must also note, however, that despite these challenges, it has also been our experience that there are pockets of primary care excellence in this province that we can learn from; to this end, we provide a few examples later in this paper.

TABLE 1: WHAT WENT WRONG IN ALBERTA?

\begin{tabular}{|l|l|l|l|}
\hline \multicolumn{1}{|c|}{ Feature } & \multicolumn{1}{|c|}{ Problem } & \multicolumn{1}{c|}{ Examples } & \multicolumn{1}{c|}{ Consequences } \\
\hline $\begin{array}{l}\text { Initiative } \\
\text { funding was } \\
\text { tied to } \\
\text { physician } \\
\text { negotiations }\end{array}$ & $\begin{array}{l}\text { All PCN funding flowed } \\
\text { through physicians. }\end{array}$ & $\begin{array}{l}\text { The July 2012 Auditor's report states that } \\
4 \text { per cent to } 62 \text { per cent of PCN funds } \\
\text { were allocated to physicians for services } \\
\text { other than fee-for-service patient care. }\end{array}$ & $\begin{array}{l}\text { Encouraged a sense of entitlement to the } \\
\text { funds among many physicians and created } \\
\text { confusion and disenfranchisement of other } \\
\text { disciplines on the team. Politicization of } \\
\text { funding - primary care reform funding } \\
\text { became a bargaining chip. }\end{array}$ \\
\hline $\begin{array}{l}\text { Systems of } \\
\text { oversight }\end{array}$ & $\begin{array}{l}\text { No clear guidelines as to } \\
\text { how the money allocated } \\
\text { should or should not be } \\
\text { spent. }\end{array}$ & $\begin{array}{l}\text { Financial reporting templates lacked the } \\
\text { level of detail required to ensure } \\
\text { expenditures were appropriate. }\end{array}$ & $\begin{array}{l}\text { Without better systems in place } \\
\text { "inappropriate expenditures may go } \\
\text { unreported and the achievement of } \\
\text { program objectives could be } \\
\text { compromised." }\end{array}$ \\
\hline
\end{tabular}

7 Starfield, Barbara, Shi Leiyu, and James Macinko (2005). "Contribution of Primary Care to Health Systems and Health," Milbank Quarterly 83(3).

8 Saher (2012) op. cit p. 31.

9 Ibid., 50 .

10 Ibid., 51. 
TABLE 1: WHAT WENT WRONG IN ALBERTA? (cont'd)

\begin{tabular}{|c|c|c|c|}
\hline Feature & Problem & Examples & Consequences \\
\hline $\begin{array}{l}\text { Accountability } \\
\text { framework }\end{array}$ & $\begin{array}{l}\text { No clearly defined } \\
\text { outcomes or measures. }\end{array}$ & & $\begin{array}{l}\text { The province was unable to determine the } \\
\text { effectiveness of various PCN models in order } \\
\text { to adequately inform future progress. There } \\
\text { was no ability to demonstrate to the public } \\
\text { whether or not PCN objectives had been } \\
\text { met, }{ }^{11} \text { but every ability for PCNs to continue } \\
\text { to receive and deploy resources without any } \\
\text { demonstration of net benefit. }\end{array}$ \\
\hline $\begin{array}{l}\text { Objectives of } \\
\text { the initiative }\end{array}$ & $\begin{array}{l}\text { The objectives were } \\
\text { broad and vague. } \\
\text { Examples related to } \\
\text { objectives } 1 \text { and } 5 \text { are } \\
\text { presented here. The } \\
2012 \text { Auditor's report } \\
\text { provides more } \\
\text { information on all five } \\
\text { objectives. }\end{array}$ & $\begin{array}{l}\text { Objective 1: "Increase the proportion of } \\
\text { residents with ready access to primary } \\
\text { care." }^{12} \\
\text { Objective 5: "Facilitate the greater use of } \\
\text { multidisciplinary teams to provide } \\
\text { comprehensive primary care." } \\
\text { (Auditor General) report, p. } 37 \text { ) The } \\
\text { language is permissive, and does not } \\
\text { state a requirement to establish team- } \\
\text { based care. }\end{array}$ & $\begin{array}{l}\text { This allowed a variety of interpretations of } \\
\text { whom "residents" included, and } \\
\text { communicated no requirement to establish } \\
\text { formal panels/rosters. This diminished the } \\
\text { emphasis on (and support for) clear } \\
\text { definition of the practice population. } \\
\text { "Ready" was also variously defined. It is } \\
\text { difficult to measure access or, for that } \\
\text { matter, any indicator without having sound } \\
\text { knowledge of the denominator (the roster). } \\
\text { There is a wide variation in use of } \\
\text { multidisciplinary teams. In } 2010-2011 \text {, } \\
\text { compensation to non-physician health-care } \\
\text { providers in PCNs varied from } 0 \text { per cent to } \\
65 \text { per cent of expenses. }{ }^{14}\end{array}$ \\
\hline $\begin{array}{l}\text { Business } \\
\text { planning }\end{array}$ & $\begin{array}{l}\text { The business planning } \\
\text { template was based on } \\
\text { a basket-of-services } \\
\text { philosophy. }\end{array}$ & $\begin{array}{l}\text { A basket-of-services (checklist) approach } \\
\text { encouraged many examples of "carve-out } \\
\text { care" i.e., boutique, stand-alone specialty } \\
\text { clinics. In numerous cases, there was } \\
\text { duplication of services with those } \\
\text { provided by AHS or other community } \\
\text { organizations. }\end{array}$ & $\begin{array}{l}\text { This wastes resources, and undermines the } \\
\text { integration of whole person-oriented } \\
\text { comprehensive primary care. }\end{array}$ \\
\hline Governance & $\begin{array}{l}\text { Reform needs a major } \\
\text { paradigm shift requiring } \\
\text { clear vision, broad } \\
\text { collaboration and buy- } \\
\text { in, significant change } \\
\text { management, public } \\
\text { engagement, and strong } \\
\text { political will. PCN } \\
\text { governance structures } \\
\text { did not demonstrate } \\
\text { these characteristics. }\end{array}$ & $\begin{array}{l}\text { The PCN legal models were set up as } \\
\text { joint ventures between primary care } \\
\text { physicians and the former health regions. } \\
\text { Further, there was no public involvement } \\
\text { in governance, and no attempt to engage } \\
\text { the public even to manage public } \\
\text { expectations. }\end{array}$ & $\begin{array}{l}\text { Even in regions (such as the former Chinook } \\
\text { Health Region) where there was a clear } \\
\text { intent to collaborate across the system, } \\
\text { there was a perception of encroachment on } \\
\text { physician autonomy; this perception grew as } \\
\text { turbulence in the health system accelerated } \\
\text { and decision-making at the local level } \\
\text { became more cumbersome. AHS } \\
\text { consolidation has also broken many of the } \\
\text { former relationships between provider } \\
\text { teams. There is a lack of public awareness } \\
\text { of the PCN initiative and the role of the } \\
\text { public in reforming primary care. }{ }^{15}\end{array}$ \\
\hline
\end{tabular}

11 The largest provincial evaluation of PCNs was conducted by hired consultants Malatest and Associates, at a cost of $\$ 1.9$ million. Ultimately however, it was not possible for the evaluators to obtain objective quantitative data to substantiate any provincial improvements, nor were they able to compare various PCN models or determine that the overall objectives had been met. The majority of their data came from patient or provider interviews/surveys, which showed marginal improvements. Even in the areas where there was more reported improvement in care such as screening and patient teaching between PCN and non-PCN patients, it was not possible to directly associate this with PCN involvement, due to an absence of baseline measurement.

12 Saher (2012) op. cit. p. 36.

13 Ibid., 37.

14 Ibid., 31.

15 Ibid., 25. 
TABLE 1: WHAT WENT WRONG IN ALBERTA? (cont'd)

\begin{tabular}{|c|c|c|c|}
\hline Feature & Problem & Examples & Consequences \\
\hline $\begin{array}{l}\text { Quality } \\
\text { improvement } \\
\text { culture }\end{array}$ & $\begin{array}{l}\text { Patchy adoption of a } \\
\text { quality improvement } \\
\text { culture. }\end{array}$ & $\begin{array}{l}\text { The AIM program was introduced in } \\
\text { Alberta to assist PCNs with the tools and } \\
\text { support to guide transformation. However, } \\
\text { there was no clear expectation that PCNs } \\
\text { participate in AIM. For those who did, } \\
\text { there was no requirement for } \\
\text { standardized measurements or reporting. } \\
\text { In the last few years, standardized } \\
\text { measures have been developed. }\end{array}$ & $\begin{array}{l}\text { Consistent QI with proven models (such as } \\
\text { IHI Triple Aim) is an important, evidence- } \\
\text { based enabler of change; to inconsistently } \\
\text { employ the strategy is to lose the } \\
\text { opportunity and slow progress. }\end{array}$ \\
\hline IM/IT & $\begin{array}{l}\text { Lack of interoperability, } \\
\text { and therefore ability to } \\
\text { share information across } \\
\text { the system, continues to } \\
\text { be a barrier to integration. }\end{array}$ & $\begin{array}{l}\text { The approach to assisting clinics to move } \\
\text { to an EMR (Physician Office Support } \\
\text { Program - POSP initiative) was intended } \\
\text { to reduce the number of possible } \\
\text { systems, but still offered choices of } \\
\text { systems. Taber Clinic chose one of the } \\
\text { approved systems, and did significant } \\
\text { work with in-house expertise to enhance } \\
\text { its functionality to maximally serve the } \\
\text { clinic. However, extended team members } \\
\text { cannot access clinic documentation } \\
\text { through their AHS system. }\end{array}$ & $\begin{array}{l}\text { Lack of informational continuity; } \\
\text { fragmented communication across the } \\
\text { system. This can lead to fragmented care } \\
\text { and miscommunication among providers } \\
\text { and between providers and patients. }\end{array}$ \\
\hline $\begin{array}{l}\text { Coordinated } \\
\text { research } \\
\text { strategy }\end{array}$ & $\begin{array}{l}\text { The initiative did not } \\
\text { include funding for } \\
\text { ongoing, coordinated } \\
\text { research to enhance and } \\
\text { leverage knowledge } \\
\text { development in primary } \\
\text { care reform. }\end{array}$ & $\begin{array}{l}\text { In one study, researchers examined the } \\
\text { impact of PCNs on the care and } \\
\text { outcomes of diabetic patients. }{ }^{16} \text { They } \\
\text { noted improvements in blood sugar } \\
\text { control, appropriate use of medications } \\
\text { and a decrease in emergency and } \\
\text { hospitalization, although it was not } \\
\text { possible to establish causality due to } \\
\text { wide variations in structure and practices } \\
\text { amongst PCNs. Others have studied the } \\
\text { optimization of the role of nurses within } \\
\text { primary care; }{ }^{17} \text { how practice was } \\
\text { changing in the new environment and } \\
\text { organizational factors that either assisted } \\
\text { or impeded the transition; }{ }^{18,19} \text { the } \\
\text { contextual influences in the development } \\
\text { and implementation of PCN models; }{ }^{20} \\
\text { and the contributions of strong physician } \\
\text { leadership, a strong project manager and } \\
\text { a goal-focused strategy in facilitating } \\
\text { positive change in eight PCNs. }\end{array}$ & $\begin{array}{l}\text { Research projects conducted were } \\
\text { informative but stand-alone and are } \\
\text { therefore limited in scope; research was } \\
\text { not coordinated into a program of } \\
\text { research to inform the evolution of primary } \\
\text { care reform in Alberta. }\end{array}$ \\
\hline
\end{tabular}

16 Manns, Braden J. et al. (2011). "The Impact of Primary Care Networks on Care and Outcomes of Diabetes," Report - Alberta Health and Wellness and Alberta Health Services.

17 Besner, Jeanne et al. (2011). "Optimizing the Practice of Registered Nurses in the Context of an Interprofessional Team in Primary Care."

18 Chreim, S. et al. (2010). "Change agency in a primary care context: the case of distributed leadership," Health Care Manage Rev 35(2).

19 Reay, Trish et al. (2012). "Legitimizing New Practices in Primary Health Care," Health Care Manage Rev.

20 Scott, Cathy and Laura Lagendyk (2012). "Contexts \& Models in Primary Healthcare and their Impacts on Interprofessional Relationships," Canadian Health Services Research Foundation.

21 Reay et al. (2012) op. cit. 
We have seen tremendous growth in PCNs, with over 70 per cent of Alberta primary care physicians now belonging to one of $40 \mathrm{PCNs}^{22}$ The province has continued to invest heavily in the initiative - a total of $\$ 700$ million up to 2012 , with another $\$ 170$ million investment committed for 2012-2013. ${ }^{23}$ Certainly, there has been some local evidence generated around PCNs, resulting in some lessons learned. However, even the most optimistic investor would have to admit that we have little evidence to demonstrate the value obtained from our investment. A recent audit of PCNs revealed concerns over an overall lack of attention to accountability and clarity of expectations, hampering the ability to evaluate their effectiveness. ${ }^{24}$ Why is this the case? We suggest that in the main, political sensitivities around the powerful physician lobby caused the province to err on the side of sweetening, ${ }^{25}$ and not stirring the physician pot. Consequently, to encourage buy-in, stimulate painless innovation and avoid any suggestion that physician autonomy may be influenced, the original objectives put forward were broad and vague; accountability to use the money to actually change practice was not mandated, and flexibility was advanced too far under the mantra of local solutions for local problems. Secondly, it must also be noted that the other partner in the service-delivery relationship, the health region, has been experienced as unstable in form and function since the 2008 consolidation of nine health regions into the single entity of Alberta Health Services (AHS). Relationships have been disrupted, decision-making processes in AHS for a long time became confusing and protracted, and a great deal of the local corporate memory and knowledge was lost to restructuring. Primary care practices became adept at moving forward in ways that worked around AHS, resulting in greater disintegration in the primary care system. Given this persistent instability, as well as an initiative-wide inability to demonstrate progress in meeting objectives, it is understandable that the transformational move to organize the rest of the system around primary care has not been advanced. Whatever we do going forward, we need to rebuild relationships across the system, commit to a shared vision of a primary health care-oriented system with primary care at the hub, and demonstrate value beyond what can be inferred from anecdotal reports of higher patient satisfaction and small improvements in care processes. Indeed, we are encouraged by recent efforts at the provincial level to bring a broader array of stakeholders and disciplines to the planning table around the next steps in primary care reform. ${ }^{26}$ However, without a compelling and shared vision, clear objectives, and a consistently applied framework of accountability, we predict little overall progress will be made.

\section{A vision for Alberta}

So if we've been on the wrong road in Alberta, what is our vision of the right one? Based on evidence and our collective experience, we propose a vision of integrated team-based primary care that is planned, developed and delivered to serve the needs of an identified population. We envision a systemic commitment to "think primary" first and last (i.e., most health care at a primary level first, with efficient linking as needed to other sectors of care - and then closing

\footnotetext{
22 http://www.albertapci.ca/Pages/default.aspx, accessed June 2013.

23 Saher, Merwan N. (2012). "Report of the Auditor General of Alberta," p. 25.

24 Ibid.

25 Martin, Danielle (2012). "Of Honey and Health Policy: the Limits of Sweet, Sticky Substances in Reforming Primary Care," Healthcare Papers 12(2).

${ }^{26}$ http://www.health.alberta.ca/documents/PHC-MAC-Bulletin6-June2013
} 
the loop back to primary).We envision an entire health-care system in Alberta transformed around supporting high-quality, accessible, efficient and evidence-informed primary care as the hub of the system. In a primary health care-oriented system, people are engaged as team members in their own primary care, as consumers in continuous quality improvement efforts, and as community participants in shared health-system governance at the provincial and local levels. All parts of the health system understand and take on shared accountability for measuring and making progress towards improving population health, and existing services and human resources are coordinated before adding additional resources directed to address gaps in services. In order for primary care to fulfill its responsibility as the hub of an integrated primary health care-oriented system, clear objectives for primary care reform are needed, and we offer what we see as key objectives in enacting the vision. These objectives are summarized in Table 2, and are based on the critical attributes and enablers of high performing primary care that are generally very well supported in the literature. We now offer a synthesis of evidence and experience to support what we believe will get us where we need to go in Alberta, and organized by three overarching strategies: system redesign, delivery process redesign, and payment redesign.

\section{TABLE 2: ATTRIBUTES, ENABLERS AND PROPOSED OBJECTIVES FOR PRIMARY CARE REFORM}

\begin{tabular}{|c|c|}
\hline $\begin{array}{l}\text { Attributes*/ } \\
\text { Enablers }\end{array}$ & Objectives \\
\hline Access* & $\begin{array}{l}\text { All Albertans are attached to a single roster of choice, and have same-day, } 24 / 7 \text { access to their primary care } \\
\text { team. } \\
\text { a. Enhanced access to care is available through systems such as open scheduling, expanded hours, and new } \\
\text { options for communication between patients and their core team. } \\
\text { b. Care is delivered when and where the patient needs it in a culturally and linguistically appropriate manner. }{ }^{31}\end{array}$ \\
\hline $\begin{array}{l}\text { Population- } \\
\text { focused } \\
\text { accountabilities* }\end{array}$ & $\begin{array}{l}\text { Primary care services are integrated around the identified health-care needs of a defined panel/roster of } \\
\text { patients. } \\
\text { a. The core primary care team is defined based on the needs of the panel/roster of patients. Team members } \\
\text { work together to their full scopes of practice to support the patient's plan of care, and collectively take } \\
\text { responsibility at the practice level for the ongoing care of the patients. }{ }^{33,34}\end{array}$ \\
\hline $\begin{array}{l}\text { Patient } \\
\text { engagement* }\end{array}$ & $\begin{array}{l}\text { Patients and families are active partners in their care; patients actively participate in decision-making, quality } \\
\text { improvement and providing feedback to ensure that patient expectations are met. }{ }^{35}\end{array}$ \\
\hline
\end{tabular}

27 Wagner et al. (2012) op. cit.

28 Neuwirth et al. (2007) op. cit.

29 Jesmin, Shammima, Amardeep Thind, and Sisira Sarma (2012). "Does Team-Based Primary Health Care Improve Patients' Perception of Outcomes? Evidence from the 2007-08 Canadian Survey of Experiences with Primary Health," Health Policy 105(1)

30 Lerberghe et al. (2008) op. cit p. 50.

31 Ibid.

32 Kates, Nick et al. (2012). "Framework for Advancing Improvement in Primary Care," Healthcare Papers 12(2).

33 Grumbach and Bodenheimer (2004) op. cit.

34 Kates et al. (2012) op. cit.

35 Ibid. 


\begin{tabular}{|c|c|}
\hline $\begin{array}{l}\text { Attributes*/ } \\
\text { Enablers }\end{array}$ & Objectives \\
\hline Continuity* & $\begin{array}{l}\text { The physician is part of a core team that coordinates to preserve relational continuity. }{ }^{36,37} \text { Each patient has an } \\
\text { ongoing relationship with the physician within the team, and the team is trained to provide first-contact, continuous } \\
\text { and comprehensive whole person-oriented care. }\end{array}$ \\
\hline $\begin{array}{l}\text { Coordination } \\
\text { and service } \\
\text { integration* }\end{array}$ & $\begin{array}{l}\text { Care is coordinated and existing/new services are integrated across all elements of the complex health-care } \\
\text { system and connected to the primary care hub (i.e., home care, chronic disease management, public health, } \\
\text { addictions and mental health, medical specialty, hospital, continuing-care nursing homes, supportive living). }{ }^{39,40}\end{array}$ \\
\hline $\begin{array}{l}\text { Comprehensive } \\
\text { whole-person } \\
\text { care* }\end{array}$ & $\begin{array}{l}\text { The core team is responsible for providing comprehensive, whole-person care, or arranging needed care with other } \\
\text { qualified professionals across the system. } \\
\text { a. Primary care teams also understand the broader health needs of the community, and are partnered with local social } \\
\text { and community service organizations to assist in meeting the identified health needs of the defined population. }{ }^{42}\end{array}$ \\
\hline Team care* & Team care is an attribute inherent in all objectives. \\
\hline $\begin{array}{l}\text { Quality } \\
\text { Improvement }\end{array}$ & $\begin{array}{l}\text { All primary care teams will engage in continuous quality improvement using proven principles and approaches, }{ }^{43} \\
\text { and measure and report on a core list of provincial performance measures, and on selected clinical indicators as } \\
\text { relevant to the population served. }\end{array}$ \\
\hline Technology & $\begin{array}{l}\text { Technology is selected for its integrated application across the system, and used appropriately to support optimal, } \\
\text { evidence-informed patient care, as well as performance measurement, patient education, enhanced access, and } \\
\text { communication between patients and teams and across teams and settings. }{ }^{46}\end{array}$ \\
\hline $\begin{array}{l}\text { Payment to } \\
\text { align incentives }\end{array}$ & $\begin{array}{l}\text { Payment appropriately recognizes and supports achievement of collaboration, preventative care delivery, care } \\
\text { continuity, comprehensiveness, and teamwork and care quality. } 47\end{array}$ \\
\hline $\begin{array}{l}\text { Shared } \\
\text { governance and } \\
\text { community } \\
\text { engagement }\end{array}$ & $\begin{array}{l}\text { The primary care practice has accountabilities to the larger community as a contributor to overall population } \\
\text { health. }{ }^{48} \\
\text { a. Primary care practices have mechanisms for engaging in community efforts to identify health and health-care } \\
\text { needs of their panel as part of the larger community. } \\
\text { b. All governance structures for primary care at the provincial and local levels demonstrate citizen involvement. }{ }^{51}\end{array}$ \\
\hline
\end{tabular}

${ }^{36}$ Schoen et al. (2007) op. cit.

37 Yarmall et al. (2009) op. cit.

38 Starfield, Leiyu, and Macinko (2005) op. cit.

39 Kates et al. (2012) op. cit.

40 Johnson et al. (2012) op. cit.

41 Friedberg, Hussey, and Schneider (2010) op. cit.

42 Kates et al. (2012) op. cit.

43 Baskerville, Liddy, and Hogg (2012) op. cit.

44 Kates et al. (2012) op. cit.

45 McMurchy (2009) op. cit.

46 Kates et al. (2012) op. cit.

47 McMurchy (2009) op. cit.

48 Community engagement and participation has appeared in some, but not all discussions of primary care-oriented health systems since the principles of primary health care were outlined in the 1978 Alm-Ata Declaration on Primary Health Care, and recently reaffirmed by the WHO as important. In this literature, community participation is framed as engaging specific groups in a defined area in identifying health needs, and also providing input into governance with a role in decision-making around mechanisms to ensure action and accountability to improve health (and health care), and distribute health services equitably. In most literature outlining the key attributes of high-performing primary care systems, however, this broader framing of community engagement is notably absent, and engagement as a core attribute is limited to the involvement of individual patients in care. In light of the Alberta Auditor General's finding that public accountability in primary care reform is lacking, we have included citizen involvement as an important enabling feature.

49 Lerberghe et al. (2008) op. cit.

50 Bhatia and Rifkin (2010) op. cit.

${ }^{51}$ Ellison (2012) op. cit. 


\section{MOVING FORWARD IN ALBERTA: SYSTEM REDESIGN}

\section{Health system governance must reflect the vision for primary care}

The vision requires an approach to governance that places primary care at the hub of the system, and lays out clear expectations for all primary-level service programs and organizations to align and integrate around the primary care hub. This horizontal integration around primary care is foundational and must be followed by the alignment and coordination of specialty/tertiary services to also support the primary care hub. At the provincial level, we believe this requires an overarching commitment to shared leadership between government and all health service sectors (acute care, primary care, community health and public health, home care, specialty care/tertiary care) and across health disciplines. The consolidation of healthservices leadership at the provincial level in Alberta facilitates such shared leadership in health, although the development of mechanisms to integrate the leadership of primary care physicians, other health disciplines and members of the public into this shared governance approach, guided by a shared vision, are required. Evolution towards a governance structure that enables a broader primary health-care approach would ultimately be supported by crossministry participation in governance, and a strategic focus on the health of Albertans in the broadest sense. Indeed, there are lessons to be learned in this regard emerging from the crossministry work that has been undertaken with the Alberta Addictions Strategy. ${ }^{52}$

A provincial governance structure must assume leadership for outlining a provincial accountability framework for primary care and for services aligned around the primary care hub; this includes defining and monitoring progress on clearly and consistently defined health indicators for all care sectors, enabling the collection of comparative data over time. Nested within a provincial governance model that is equipped with a clear vision and consistent expectations of accountability, a level of governance around primary care needs to devolve to the more local level - although what constitutes a local community is always more complex to define than it sounds. ${ }^{53}$ Although we believe it is essential to first investigate the local understanding of what constitutes the community, rather than assuming that geography always defines community boundaries, the recent work done by Alberta Health Services in defining "health service areas" ${ }^{4}$ may be a logical place to begin. Local governance around primary care for a defined population would need to commit to shared leadership and bringing all primary health services to the table, which we believe was the intent, however unrealized, of the original joint venture model and networked approach proposed in the PCN initiative. Even in parts of the province where a more shared leadership model was adopted, however, the scope remained narrowly confined to health-authority leadership and primary care physicians.

52 “Creating Connections: Alberta's Addiction and Mental Health Strategy," (2011). Government of Alberta.

53 Neuwelt, Paul M. (2012). “Community Participation in Primary Care: What Does it Mean 'in Practice'?” Journal of Primary Health Care 4(1).

54 Preddy, G. N. et al. (2011). "How Healthy Are We? 2010 Report of the Senior Medical Officer of Health," Alberta Health Services Population \& Public Health. 
Although leadership to support service integration around the primary care hub at the local level might start with health-service program leaders and primary care entities, we believe the goal should be to broaden the local governance model to engage members of the larger community. Here, we can learn from research done in the UK, where researchers have examined different forms of community engagement in the governance of primary care..$^{55,56,57}$ They emphasize the importance of clarity of purpose of participation and whether it is framed as the involvement of consumers, or the more general involvement of citizens. Others have found that community participation is an important mechanism to gain knowledge from communities about broader issues affecting health, to learn about inequities in resource distribution and how services are perceived, ${ }^{58}$ and to ensure accountability in the allocation of resources to improve the health of a community ${ }^{59}$ Community participation, at its heart, should be about building relationships and trust between health services and citizens, and creating opportunities for meaningful information sharing and learning - thereby linking directly to continuous quality improvement in primary care. ${ }^{60}$ Given the desired primary health-care orientation for reform in Alberta, we believe that a transformed primary care practice also has a role as a concerned "citizen" of the community, with accountability for contributing to the overall health of a community. We believe in the expectation for primary care to contribute to (but not encapsulate) primary health care. The transformed primary care practice engages with its community in shared initiatives to promote health that are particularly germane to the health needs of the panel. Partnerships with broader health and social service organizations cannot be attempts to force a health-service lens on their services, but to acknowledge that the "primary care home" cannot possibly meet all the broader health needs of a defined population; it is, instead, a strategy to mobilize additional resources, build connections and improve cross-sector communication and coordination around improving the health of the population. ${ }^{61}$

55 Alborz, Alison, David Wilkin, and Keri Smith (2002). "Are Primary Care Groups and Trusts Consulting Local Communities?" Health and Social Care in the Community 10(1).

56 Pickard, Susan and Keri Smith (2001). “A 'Third Way’ for Lay Involvement: What Evidence so Far?” Health Expectations 4(3).

57 Milewa, Timothy and Micheal Calnan (2000) "Primary Care and Public Involvement: Achieving a Balanced Partnership," Journal of Royal Society of Medicine 93.

58 Neuwelt (2012) op. cit. p. 4.

59 Bhatia and Rifkin (2010) op. cit. p. 6.

${ }^{60}$ Neuwelt, ibid.

61 In an example shared with us by Lorna Milkovich, RDPCN Executive Director, March 19, 2013, she noted that the Red Deer Primary Care Network has embraced the Wagner's Expanded Chronic Care Model integrating community action along with health services. Recognizing their role as credible and visible advocates for health in their community, they have enacted engagement by catalyzing action around obesity - an issue identified as increasing health risk in their population. Leveraging existing resources, networks and events in the community, team members participate in moving physical activity initiatives forward, but in ways that acknowledge that the community owns these initiatives, with the PCN being only one of many community participants. 


\section{Accountability to meet the health-care needs for a defined population of Albertans}

Population-focused care is planned and designed to meet the identified and predictable needs of an identified population, and is a crucial step in improving population health outcomes. ${ }^{62}$ Establishing accountability for the health-care needs of a population in primary care requires understanding the health needs, and then establishing a connection between the provider team and those served. There are different ways to define the population. Although it has been demonstrated that placing people on a primary care list of patients for a particular primary care provider (enpanelment) based on geographic proximity to the practice is not necessarily effective, ${ }^{63}$ it has been a useful approach in rural areas where people tend to seek primary care close to home (such as Taber). Another more common method is attaching patients to practice panels based on patterns of primary care utilization; this is a somewhat passive approach, and typically does not include seeking commitment from patients to the primary care attachment. This was the method used to establish PCN panels. Known as the "4-cut method" of attachment, ${ }^{64}$ it was based on physician billing data and a visit history for a physician. The failure was in placing too much faith on the results of the 4-cut method as a proxy for patient choice on where to seek service..$^{65}$ This assumption was flawed, resulting in many Albertans remaining wholly unaware that they had been attached to a particular practice. ${ }^{66}$ This is a hollow view of attachment, and negates one of the main values of attachment in the first place: providers and patients knowing and trusting one another, in a relationship that continues over time. ${ }^{67}$

Building the accountability called for in the Auditor General's report ${ }^{68}$ requires mechanisms to ensure attachment, including mutual confirmation, and even contractual agreement between patients and providers. This is rostering, where individuals formally attach to a chosen healthcare provider and team. ${ }^{69,70}$ Progress towards the vision in Alberta would also be supported by central, provincial coordination of attachment information in the form of a central registry, in

62 Lynn, Joanne et al. (2007). "Using Population Segmentation to Provide Better Health Care for All: The "Bridges to Health” Model," The Millbank Quarterly 85(2): 186-187.

63 Fortney, John C. et al. (2005) “Does Improving Geographic Access to VA Primary Care Services Impact Patients' Patterns of Utilization and Costs?" Inquiry 42(1): 38.

64 Primary Care Initiative (2007). "Funding a Primary Care Network: Four-Cut Funding Methodology," accessed March 6, 2013. www.albertapci.ca

65 To be fair, the 4-cut method was only ever intended to be an approximation, or initial sorting of patients to providers. There was always an expressed intent to refine the process, but this never happened provincially.

66 Saher (2012) op. cit. p. 42.

67 Tarrant, Carolyn et al. (2010). "Continuity and Trust in Primary Care: A Qualitative Study Informed by Game Theory," Ann Fam Med 8(5).

68 Saher, ibid. p. 8.

69 Menec, Verena et al. (2000). "Defining Practice Populations for Primary Care: Methods and Issues," p. 8-9.

70 Crowfoot Village Family Practice in Calgary was an early exemplar of formal rostering in the Alberta context in a capitated payment model, although rostering is not tied to any one remuneration model. The lessons from their experience are instructive. The process of rostering, they noted, takes time. They recommended a gradual shift over a period of approximately six months in order to allow for adequate training of staff, invitation and subsequent communication with patients of the practice, digitization of the practice roster, and the establishment of guiding policies and processes to support the growth and maintenance of an accurate roster. They also noted that while the majority of patients were very positive about joining the practice formally, some expressed suspicion about the required commitment and reacted negatively to this constraint on their choice. 
order to avoid (as much as possible) duplicate rostering to two or more primary care entities, and to assist in understanding the size and distribution of the unattached population. We acknowledge that attachment will not always be possible, as in the case of more transient, hard-to-reach populations. There is also, we know, a population of patients who don't wish to be attached. However, we believe that mechanisms must be developed to respond in a timely manner to the needs of persistently unattached populations. We also acknowledge the perspective of some that attachment is not really necessary for younger, healthier members of the population. Indeed, in terms of value for money, it has been demonstrated that the degree of attachment to a primary care practice is inversely proportional to the costs of care for patients with complex chronic illness. ${ }^{71}$ However, it is not a given that the philosophical inverse of this position is true - that those without diagnosed complexity would show no cost-benefit in terms of attachment. To the contrary, we believe that comprehensive, proactive and whole person-focused primary care has much to offer in the prevention of complexity, including many benefits to society beyond those of cost. Finally, exclusive attachment will also face challenges in terms of being interpreted by some as a restriction of choice. We believe that this is mitigated by fulfilling the promise of attachment - providing timely access to (and an ongoing relationship with) a responsive and familiar primary care team. Rostering enables a team to have good knowledge of the patient's unique history, social milieu and ongoing need, ${ }^{72,73}$ this supports proactive, planned, whole person-oriented care and helps avoid costly episodic care. ${ }^{74,75,76}$ Identifying and capturing a population in this way is also essential to assigning accountability for care and outcomes, and for enabling measurement and progress over time. ${ }^{77,78}$ Therefore, we suggest that formal rostering of all Albertans with a single primary care physician working within a team should be considered a priority goal. Central tracking of attachment will facilitate the identification of gaps and further strategies required in meeting the needs of the whole population.

Taking steps to gain a clear understanding of the health needs of the community being served is essential. It may be that this assessment of need begins with a concerted examination of the health needs and risks of the roster, followed by expansion outwards from this sub-population towards the larger community. For communities with little in the way of primary care services, it may begin with assessing the health needs of these larger underserved populations with a larger community needs assessment - an expressed expectation for the development of FCCs.

71 Hollander, Marcus J. et al. (2009). "Increasing Value for Money in the Canadian Healthcare System: New Findings on the Contribution of Priamry Care Services," Healthcare Quarterly 12(4).

72 Livaudais, Gerald, Robert Unitan, and Jay Post (2006). “Total Panel Ownership and the Panel Support Tool - "It's all About the Relationship,"' The Permanente Journal 10(2).

73 Neuwirth, Ester B. et al. (2007). "Understanding Panel Management: A Comparative Study of an Emerging Approach to Population Care," The Permanente Journal 11(3).

74 Friedberg, Mark W., Peter S. Hussey, and Eric C. Schneider (2010) "Primary Care: A Critical Review of the Evidence on Quality and Costs of Health Care," Health Affairs 29(5).

75 Schoen, Cathy et al. (2007). "Toward Higher-Performance Health Systems: Adults' Health Care Experiences in Seven Countries, 2007," Health Aff (Millwood) 26(6).

76 Starfield, Leiyu, and Macinko (2005) op. cit.

77 Wagner, Edward H. et al. (2012). "The Changes Involved in Patient-Centered Medical Home Transformation," Prim Care Clin Office Pract 39.

78 Gilfillan, Richard J. et al. (2010). "Value and the Medical Home: Effects of Transformed Primary Care," The American Journal of Managed Care 16(6). 
With either approach, it is essential to establish what primary-level services already exist to meet the needs of the population of interest. Improving primary care service delivery starts by addressing gaps in primary care service in a community; beginning with an out-of-context, a priori "basket-of-services" approach can gloss over this step. The result can be a shift of focus from service to meet demonstrated population need, to the procurement of proffered resources associated with developing the service within the walls of the primary care practice. This invites duplication of existing service elements in the community. For example, we have seen the development of numerous boutique chronic disease management (CDM) programs in primary care practices, instead of efforts to integrate with existing CDM services in a more shared-care approach.

\section{Primary-level service integration}

Coordination of health care around a population requires integration with other primary-level health-care services as well as specialty (non-primary) services, and linkage of these services to the primary care hub. Primary-level services are those that support people in their community, so they can stay or become healthy or recover from illness, and do not require the involvement of medically specialized intervention (a physician referral to a medical specialist). Evidence supports primary care as the most cost-effective way to meet most health-care needs, ${ }^{79}$ but the current system of primary-level care in Alberta is predominantly organized around each primary-level service as a separate and provider-centric island of caseloads - a typical approach internally organized around system and provider needs ${ }^{80}$ and detrimental to care coordination. Coordination of care is about smooth transitions with warm handoffs between connected providers; handoffs that minimize discontinuity by ensuring comprehensive information is shared, that trust in relationships is valued, a whole picture of care is communicated, and care is planned to happen at the right time to meet patient need. ${ }^{81,82}$ Coordination of care is essential within primary care and also at the system level in order to reduce duplication of services and promote integration with the rest of the health-care system. Evidence tells us that this is greatly facilitated by clear communication through mechanisms such as standardized referral processes and continuity of patient information across the system..$^{83,84,85,86}$

\footnotetext{
79 Starfield, Leiyu, and Macinko (2005) op. cit.

${ }^{80}$ Lynn et al. (2007). op. cit. p. 186.

81 Ehrlich, Carolyn, Elizabeth Kendall, and Heidi Muenchberger (2012)."Spanning Boundaries and Creating Strong Patient Relationships to Coordinate Care Strategies Used by Experienced Chronic Condition Care Coordinators," Contemporary Nurse: A Journal for the Australian Nursing Profession 42(1).

82 Johnson, Julie K. et al. (2012). "Searching for the Missing Pieces Between the Hospital and Primary Care: Mapping the Patient Process During Care Transitions," BMJ Qual Saf 21 Suppl 1.

83 Haggerty, Jeannie L. et al. (2008). "Practice Features Associated with Patient-Reported Accessibility, Continuity, and Coordination of Primary Health Care," Annals of Family Medicine 6(2).

84 Maeng, Daniel D. et al. (2012) "Reducing Long-Term Cost by Transforming Primary Care: Evidence from Geisinger's Medical Home Model," American Journal of Managed Care 18(3).

85 Thomas, Mary Booth et al. (2010). "Patient-Centered Medical Home Model Focuses on Care Coordination," Case Management Advisor 21(4).

86 Thomas, Mary Booth et al. (2011). "Accountable Care Organizations Emphasize Prevention, Coordination," Case Management Advisor 22(1).
} 
Leaders committed to a system that puts citizen health-care need at the centre must commit to reorganizing health services around where that need typically presents and is met: primary care. We must set the expectation and support the realignment of other primary services like home care, CDM, mental health and addictions counseling, and public health around the primary care hub, with professionals from these services becoming extended team members of the primary care practice team. ${ }^{87}$ This kind of service realignment invites efficient use of existing resources, and also creates the opportunity to look at our primary care-level workforce in a much more integrated way. For example, when the focus on integration of services around primary care began in the former Chinook Health Region, home-care case managers were skeptical. It had been their experience that they had to "pick up the pieces" for "their" clients because primary care practices had been largely inaccessible as a source of timely support. This frequently resulted in home-care clients being directed to an emergency department to receive services that could have been provided in primary care. Conversely, primary care physicians often reported an inability to contact the home-care case manager assigned to one of their patients in order to follow up on identified issues. Not only did this create frustration, and pit one primary service against another, it was a missed opportunity to incorporate the skills of home-care nurses - complex care case managers - into the management of the practice population. In projects conducted by the Canadian Home Care Association, ${ }^{88}$ alignment of home-care case managers with family health teams produced benefits such as improved management of chronic disease, increased coordination of complex care, reduced fragmentation of care and increased linkages between community services and patients. Indeed, Alberta is now positioned for this type of integration, given the recent work undertaken by Alberta Health Services to enhance the complex case management skills of home-care case managers. ${ }^{89}$ Bringing this skill set to bear within the context of primary care leverages the opportunity to mobilize and coordinate other community resources and services to support the panel, and create partnerships between these additional related services and the primary care hub.

${ }^{87}$ For example: community-based, interdisciplinary healthy lifestyle and chronic disease management programming exists as a part of the Alberta Health Services infrastructure in the urban community of Lethbridge. The members of this team are expert in the lifestyle coaching and self-management support of people living with chronic disease, and in the more specialized support of individuals struggling with complex management issues related to diabetes, heart failure, and chronic lung disease. These team members are assigned caseloads that correspond with the panels of practices in the local PCN so that care can be shared and coordinated. These extended team members are considered a critical part of the primary care practice team, and space/time are arranged for these extended team members to be present in the practice to support patients during clinic visits. These extended team members also invest substantial time and effort in developing the knowledge and skills of core team members that work daily in the primary care practice, enhancing the ability of the whole team to deliver ongoing, evidence-informed chronic disease management as part of the core team's commitment to whole-person care - and so that exacerbations of illness are avoided as much as possible.

88 "Health System Integration: Synthesis Report," (2012). Canadian Home Care Association, pp. 15-16.

89 Swanson, Signe and Kathryn Brandt (2011). "Progressing the Continuing Care Strategy: Continuing Care Case Management Framework \& Guidelines," Alberta Health Services Seniors Health Strategy Portfolio. 


\section{Specialty-level service integration}

We have seen an emphasis in Alberta on strategic clinical networks (SCNs) ${ }^{90}$ that appear to be designed to support a specialty focus on specific diseases or conditions in the health-care system. Evidence tells us that systems built around disease-specific specialty care obtain better disease-specific outcomes, but result in higher costs and higher rates of all-cause mortality. ${ }^{91}$

Moreover, the bulk of chronic disease management happens in primary care - and much of that care is for people living with more than a single chronic condition. What is required now is a clearly articulated vision or plan for how these specialty networks will connect with a whole person-focused, horizontally integrated primary care system. Even recognized centres of primary care excellence in Alberta acknowledge that one of the big gaps is coordinated and timely access to specialty care for their patients.

Part of the solution lies in enhancing the capacity of primary care to better manage complexity, which has the effect of reducing the need for specialty care referral - a supported and appropriate "pull to primary." 92 For example, primary care physicians in a Family Health Team in Kitchener, Ontario recognized three very important factors influencing their practice population: a rising incidence of dementia, a general lack of knowledge and confidence in their primary care clinicians in supporting/managing patients living with dementia, and a lengthening wait for specialized geriatrician services. ${ }^{93}$ They believed that they could do a better job of providing evidence-informed dementia diagnosis and care in primary care, thereby supporting earlier diagnosis and intervention and avoiding the need to divert so many of their patients to specialty care. Therefore they developed, in collaboration with local geriatricians, a primary care memory clinic. This service was planned and provided within the practice, by primary care team members who received additional training and ongoing consultative support from the collaborating specialists around the assessment and treatment of dementia. One of the key goals of this strategy was to build capacity within the practice, increasing the knowledge, skill and confidence of all providers in the practice to better support the complexity of dementia care at the primary level. They reported high patient and provider satisfaction with the approach, significant gains in the knowledge and confidence of providers in the practice, reductions in the delay for patients to receive appropriate assessment, and a dramatic reduction in the need for specialist referral. ${ }^{94} \mathrm{~A}$ similar approach to expanding the capacity of primary care to appropriately manage more medical complexity in heart failure is exemplified by the Heart Failure Network: the approach has resulted in a >50 per cent drop in emergency room utilization for heart failure cases, and significant reductions in hospital readmissions for heart failure in southern Alberta, ${ }^{95}$ these results have been sustained. ${ }^{96}$

\footnotetext{
90 http://www.albertahealthservices.ca/scn.asp, accessed.

91 Starfield, Leiyu, and Macinko (2005). op. cit.

92 The underlying belief here is consistent with the principle of continuity: outcomes are better when care is provided by team members who know the patient; it is also true that care must be evidence-informed and appropriate. Referral to scarce, specialty resources outside the practice should be limited to only those patients who are most complex and whose needs exceed the resources, skills and knowledge of the primary care practice. Therefore, enhancing the resources, skills and knowledge of the practice is a logical step in reducing the demand for specialty care.

93 Lee, Linda et al. (2010). "Enhancing Dementia Care: a Primary Care-Based Memory Clinic," J Am Geriatr Soc 58(11).

94 Ibid, p. 2202.

95 Penner, Jennifer (2010). "Evaluating the Heart Function Clinic and Heart Failure Network: A System-wide Approach to Heart Failure Care in AHS-Chinook." Paper presented at Alberta Cardiac Access Collaborative, Edmonton, Alberta, January 2010.

96 Personal communication with Jennifer Penner (HFN Lead Clinician), March 19, 2013.
} 
There are specialized services, of course, that cannot be pulled to primary, and require the direct intervention of a medical specialist. In this case, medical gatekeeping for this expensive, scarce resource is the typical approach in Canadian health care (i.e., the primary-level medical provider acts as a gateway to specialist services by providing a required referral to specialty care as a first step). Gatekeeping is really the insertion of an inspection step to ensure that use of these scarce resources is targeted and appropriate; that step is best placed, it would seem, where the patient is best known. It makes sense then that access to a medical specialist should continue to be coordinated through a primary care gatekeeper. Unfortunately, in the current political climate in Alberta, gatekeeping has been framed in a way that makes it seem to be about larger issues of control. Gatekeeping is not (and should not) be about who the boss is, who the money flows through, or what profession is the most important in the design of the service - gatekeeping must be about appropriate, coordinated and timely specialty care. The goal is a smooth and timely handoff between primary and secondary care, thereby reducing delay and care fragmentation. For example, one area that is vulnerable to fragmentation in care is the connection between in-patient acute care services and primary care. We suggest that this has been made worse as we see an increasing number of primary care physicians retreat from hospital care, and the resulting introduction of the hospitalist role in many Alberta hospitals (where a hospital-based physician coordinates all in-hospital medical care). While a debate on the use of hospitalists is beyond the scope of this paper, there is evidence that without planned and consistent efforts to ensure a smooth handoff back to primary care, the comprehensiveness of care can be eroded..$^{97,98}$

\section{Measuring performance}

System redesign requires consistently defined and measured performance indicators and supports to meet expectations. An accountability and performance management framework based on clear goals and consistently defined indicators is a critical attribute that is lacking in most Canadian innovation for primary care reform. ${ }^{99}$ It is an essential and urgent priority in Alberta to establish a robust, mandatory accountability and performance management framework around primary care that reflects the core attributes of strong primary care systems, focuses on improving the value and quality of care provided to patients/population, and promotes continuity of care and integration across health-care services. The value of clear messages about what is expected, and consistently defined measures focused on how well we are collectively meeting goals and making progress, cannot be overstated. We recognize that the requirement for measurement is not new to many primary care practice teams in Alberta that have engaged in the PCN initiative, but we know that for many, it continues to be challenging; we also recognize that the introduction of provincially mandated indicators will add a measurement burden, and no small amount of political pushback from a fiercely autonomous physician-dominated culture of primary care. However, our experience in Alberta

\footnotetext{
97 Harlan, Gregory A. et al. (2012). "Improving Transiton of Care at Hospital Discharge - Implications for Pediatric Hospitalists and Primary Care Providers," Journal of Healthcare Quality 32(5).

98 Johnson et al. (2012). op. cit.

99 Mable, Ann L. and John Marriott (2012). "Canadian Primary Healthcare Policy: the Evolving Status of Reform," Canadian Health Services Research Foundation.
} 
has demonstrated that without a requirement to measure, and support to do it consistently, there is no ability to demonstrate progress or accountability for substantial investment. Ideas for a suggested accountability framework built around the core system attributes appear as an appendix to this paper. ${ }^{100}$

\section{Enabling system redesign}

Electronic medical records (EMRs) that support data capture as a function of clinical documentation on the selected indicators are critical to reduce the burden of measurement. Effective EMRs also allow for the use of tools such as chronic disease registries, clinical decision-support tools (such as care guidelines), point-of-care prompts and reminder systems, which are important components of chronic care management. ${ }^{101,102}$ Automated care rules and reminders, coupled with an expectation that all team members will follow up on the reminders also support a culture of shared accountability. ${ }^{103}$ Primary care teams have told us that finding the right EMR can be challenging, but is essential in supporting proactive, team-based care and enabling measurement of progress in meeting care targets for their population. Further, to support measurement across the system to support primary care, efforts to create interoperability of electronic documentation systems across health-care sectors must continue.

A robust and long-term quality improvement strategy is a key enabler of health-care system redesign. ${ }^{104}$ Quality improvement requires strong, engaged leadership and expertise in change management in order to remove barriers and create a culture of continuous improvement. ${ }^{105}$ Further, change is facilitated by having staff at all levels engaged in the process of improvement, as well as having local champions leading the change. ${ }^{106}$ In our work in Chinook, we noted that the most successful practices had physician champions fully engaged

\footnotetext{
${ }^{100}$ See Appendix 1. The indicators referenced in each category are among the best measures currently available at the primary care level to reflect performance on each attribute. Although there are no perfect indicators, we have attempted to include meaningful indicators that reflect current thinking in quality measurement, and that align with our core objectives. We suggest these indicators as benchmarks for improvement and potential referents for pay-forperformance schemes. Other indicators may be added by provider teams based on the needs of their patient population. We recognize that this framework has limitations, including its focus on only the core indicators for the primary care hub; this will require ongoing refinement as Alberta proceeds with whole-system transformation around primary care. (For example: measures around access to specialty care).

${ }^{101}$ Bodenheimer, Thomas (2003). "Interventions to Improve Chronic Illness Care: Evaluating their Effectiveness," Disease Management 6(2).

102 Dorr, David A. et al. (2006). "Implementing a Multidisease Chronic Care Model in Primary Care Using People and Technology," Disease Management 9(1).

${ }^{103}$ Recent work with clinicians in Taber revealed that although accountability for good care was always a strong value in the practice, that there has been a transition in their culture. They have moved from a culture of individual accountability for good care enacted by one provider for one patient at a time, to strong and shared team accountability for each patient and for the whole panel of patients. The EMR supports this new culture in its ability to flag particular care "rules" for patients that must be completed by whoever encounters the flag. In terms of the panel, they are able to comb through the data to identify opportunities for preventive care, and then follow up as a team.

104 "Which Way to Quality? Key Perspectives on Qualtiy Improvement in Canadian Health Care Systems," (2013) Health Council of Canada.

${ }^{105}$ Kabcenell, Andrea (2012). "Creating a Culture of Excellence," Healthcare Executive.

${ }^{106}$ Kirchner, Jo-Anne E. et al. (2012). "Roles of Managers, Frontline Staff and Local Champions, in Implementing Quality Improvement: Stakeholders' Perspectives,” J Eval Clin Pract 18(1).
} 
in the work and participating in leading the change. It has been noted that in Canada, primary care physicians are often expected to take such a role in reform initiatives, yet they lack training in leadership and quality improvement. ${ }^{107}$ In fact, Canada has one of the lowest rates for physician participation in quality improvement and the setting of performance targets in comparison with countries such as Australia, New Zealand and the UK. ${ }^{108,109}$ It is our contention that the quality improvement strategy chosen must not only engage all clinicians, it must take a system-wide perspective if we desire a system integrated around the primary care hub. Strategies that limit the scope of transformation to inside the walls of the primary care practice will do little to reduce care fragmentation. This is also an area where evidence demonstrates that the contribution of the public, as consumers of the service provided, can add value. ${ }^{110,111}$

The use of learning collaboratives and facilitation are two linked strategies that have been shown to be effective in advancing system-level quality improvement initiatives..$^{112,113,114}$ The learning collaborative is a system-transformation strategy based on the principles of advanced access, and was first developed by the Institute for Health-care Improvement in the US; ${ }^{115}$ it proved to be very effective in assisting the former Chinook Health Region to become a recognized model of excellence for the health-care system. ${ }^{116}$ The Alberta model of the learning collaborative, Alberta AIM (Access, Improvement, Measurement), guides and supports primary care provider teams in applying principles that guide system improvement in access to care, practice efficiency and clinical care. ${ }^{117}$ In our experience with AIM, primary care provider teams were supported by dedicated change facilitators, a strategy that enhanced team development and enabled ongoing measurement. The practice transformation process required

${ }^{107}$ Ellison, Philip (2012). "The Challenge of Advancing Quality in Canadian Primary Healthcare," Healthcare Papers 12(2) , pp. 25-26.

${ }^{108}$ McMurchy, Dale (2009). "What are the Critical Attributes and Benefits of a High-Quality Primary Healthcare System?" pp. 8-9.

${ }^{109}$ Kirchner et al. (2012) op. cit.

${ }^{110}$ Boivin, Antoine et al. (2010). "Patient and Public Involvement in Clinical Guidelines: International Experiences and Future Perspectives," Qual Saf Health Care 19(5).

${ }^{111}$ Antoine Boivin et al. (2011). "Target for Improvement: a Cluster Randomised Trial of Public Involvement in Quality-Indicator Prioritisation (Intervention Development and Study Protocol),” Implementation Science 6(1).

${ }^{112}$ Baskerville, N. Bruce, Clare Liddy, and William Hogg (2012). "Systematic Review and Meta-Analysis of Practice Facilitation Within Primary Care Settings," Annals of Family Medicine 10(1).

${ }^{113}$ Nutting, Paul A. et al. (2010). "Effect of Facilitation on Practice Outcomes in the National Demonstration Project Model of the Patient-Centered Medical Home," Ann Fam Med 8 Suppl 1.

${ }^{114}$ Shaw, Eric K. et al. (2012). "More Black Box to Explore: How Quality Improvement Collaboratives Shape Practice Change," J Am Board Fam Med 25(2).

115 “The Breakthrough Series: IHI's Collaborative Model for Achieving Breakthrough Improvement,” (2003). Institute for Healthcare Improvement.

${ }^{116}$ Cowell, John (2012). "Review of the Quality of Care and Safety of Patients Requiring Access to Emergency Department Care and Cancer Surgery and the role and Process of Physician Advocacy."

${ }^{117}$ The advanced access model, based on the science of queuing theory, directly confronts the flaws in traditional ways of meeting the demand for primary care services - responses that involve schedule and work assignment manipulations to discern what needs are urgent and then focus resources on that first. These responses, although intuitive, have the effect of disrupting continuity with the core provider, diverting resources to "sorting" needs, and actually increasing delay. 
teams to define and take accountability for the sub-population served (panel, roster) as a first step, understand the demand for and supply of their services, and engage in proven strategies to match supply and demand in order to accomplish "today's work today." "118 The AIM program continues in Alberta and could be expanded. It is a valuable repository of experience with measurement, change management and facilitation, and the tools and strategies needed to support progress towards high-performing primary care. Additionally, many members of the AIM faculty are well-respected clinical leaders who have been through the program and are practicing in Alberta. As we also discovered, the model was scalable to allow for the inclusion of extended team members - providers from other primary-level programs (i.e., mental health, chronic disease programs, home care, etc.). This approach supported integration of previously siloed service providers with core primary care provider teams; it is positive that to some degree, a cross-program approach has been maintained in Alberta AIM. ${ }^{119}$ In the former Chinook Health Region, we had not evolved to the point of public participation in the quality improvement process; this appears like a logical next step in the evolution of system-level improvement efforts in primary health care-oriented primary care. Quality improvement strategies are numerous, and many have been adopted in various parts of the Alberta health system within specific program and service areas (lean, six-sigma, etc.). The principle that must not be diluted, however, is the necessity of focusing quality improvement on integration across the system around the primary care hub.

\section{MOVING FORWARD IN ALBERTA: PROCESS REDESIGN IN CLINICAL SERVICES}

Process redesign must be data-driven, and must begin with learning and applying the principles of advanced access described above. Clinical service redesign cannot progress until primary care practices possess a solid understanding of the panel or roster and of the demand for their services and their available supply, as well as a firm commitment to ongoing measurement. ${ }^{120}$ Comprehensive care needs to be designed around and developed to meet the health-care needs of the population more generally, and the rostered panel in particular. Processes must be transformed to support the provision of planned care, and the collection of data to allow for the monitoring of progress in improving health outcomes; ${ }^{121,122}$ this approach is a particularly important component of planned chronic illness care. ${ }^{123}$ We all have to count on the primary care sector to address a very wide scope of common health-care problems, and to leverage every contact with patients as an opportunity to promote health and prevent future illness.

\footnotetext{
${ }^{118}$ Murray, Mark and Doanld M. Berwick (2003). "Advanced Access: Reducing Waiting and Delays in Primary Care," JAMA 289(8), p. 1037.

${ }^{119}$ In an email conversation with Steven Clelland, the Provincial Director of AIM on March 28, 2013, it was confirmed that over 120 primary care teams, in collaboration with more than 70 AHS primary-level program teams and six medical specialty practices have been through AIM Collaboratives.

${ }^{120}$ Murray and Berwick (2003) op. cit.

${ }^{121}$ Margolius, David and Thomas Bodenheimer (2010). "Transforming Primary Care: from Past Practice to the Practice of the Future," Health Affairs 29(5).

${ }^{122}$ Gilfillan et al. (2010) op. cit.

${ }^{123}$ Kimura, Joe, Karen DaSilva, and Richard Marshall (2008). "Population Management, Systems-Based Practice, and Planned Chronic Illness Care: Integrating Disease Management Competencies into Primary Care to Improve Composite Diabetes Quality Measures," Dis Manag 11(1).
} 
The ability to provide comprehensive, proactive and planned primary care is beyond what can be expected of any solo primary care provider. For this reason, it is essential to redesign service delivery to incorporate the use of teams to provide care. ${ }^{124,125,126}$ There is growing evidence to support the integration of a variety of different team members into primary care teams including registered nurses,${ }^{127}$ nurse practitioners, ${ }^{128}$ pharmacists, ${ }^{129}$ social workers, ${ }^{130}$ mental health therapists ${ }^{131}$ and others. There is also evidence that the inclusion of the role of complex case manager ${ }^{132,133}$ - often a registered nurse with additional educational preparation in the management of complex conditions - has been shown to improve outcomes. ${ }^{134}$ Core teams embedded in primary care practices are most helpfully constituted by clinical providers whose scopes of practice are fully extended around participating in population management: planning and delivering whole person-oriented care for a defined population of patients over time. This leads to a discussion of what the practice population needs, in advance of a discussion of who should constitute the core team - i.e., there is no one team complement that will serve every population. Evidence also suggests, and our experience bears out, that the process of effectively integrating teams into primary care is a challenge that is all too often underestimated in its complexity, and under-supported from a change management perspective. ${ }^{135,136}$ We also learned that adding team members to perform components of care (i.e., violating the attribute of whole person-focused care) has the effect of increasing fragmentation of primary care. Finally, discussion of the core team cannot be isolated from the essential role of the primary care physician, although it is a separation fed by history and

${ }^{124}$ Yarmall, Kimberly S. H. et al. (2009). "Family Physicians as Team Leaders: "Time" to Share the Care," Public Health Research, Practice and Policy 6(2).

${ }^{125}$ Grumbach, Kevin and Thomas Bodenheimer (2004). "Can Health Care Teams Improve Primary Care Practice," JAMA 291(10).

${ }^{126}$ Kreindler, Sarah (2008). "Lifting the Burden of Chronic Disease."

${ }^{127}$ Browne, Gina (2012). "Better Care: an Analysis of Nursing and Health System Outcomes," Canadian Health Services Research Foundation.

${ }^{128}$ Jackson, George L. et al. (2011). "Employment of Mid-Level Providers in Primary Care and Control of Diabetes," Prim Care Diabetes 5(1).

${ }^{129}$ Burns, Mary A. Chilsholm- et al. (2012). "US Pharmacists’ Effect as Team Members on Patient Care: Systematic Review and Meta-Analysis," Medical Care 48.

${ }^{130}$ Geron, Scott Miyake and Bronwyn Keefe (2006). "Moving Evidence-Based Interventions to Populations: A Case Study Using Social Workers in Primary Care," Home Health Care Serv Q 25(1-2).

${ }^{131}$ Lester, Helen et al. (2007). "Cluster Randomised Controlled Trial of the Effectiveness of Primary Care Mental Health Workers," British Journal of General Practice 57.

${ }^{132}$ Maeng et al. (2012) op. cit.

${ }^{133}$ Woltmann, Emily et al. (2012). "Comparative Effectiveness of Collaborative Chronic Care Models for Mental Health Conditions Across Primary, Specialty, and Behavioral Health Care Settings: Systematic Review and Meta-Analysis," American Journal of Psychiatry 169.

${ }^{134}$ Wolber, Teresa and Deborah Ward (2010). "Implementation of a Diabetes Nurse Case Management Program in a Primary Care Clinic: a Process Evaluation," Journal of Nursing and Healthcare of Chronic Illness 2(2).

135 "Enhancing Interdisciplinary Collaboration in Primary Health Care in Canada," (2005). Conference Board of Canada.

${ }^{136}$ Dinh, Thy (2012). "Improving Primary Care Through Collaboration: Briefing 2 - Barriers to Successful Interprofessional Teams," Conference Board of Canada. 
models of remuneration. Certainly, evidence tells us that physicians are foundational to a strong primary care system. ${ }^{137,138,139,140}$ Indeed, current evidence tells us that every Albertan should have access to a primary care physician as part of a core team constituted to meet the needs of the served population. It is also clear that achieving the vision means that primary care physicians can no longer practice in a way that disregards the valuable roles played by other providers; practice transformation is required..$^{141}$

Since who constitutes the team will depend on the population, we anchor this discussion to an important principle related to building teams that was central to our learning about teams from experts from the Institute for Health-care Improvement: supplementation vs. substitution of providers. ${ }^{142}$ Supplementation refers to the principle of starting with a core primary care provider - the provider with the broadest skillset in terms of providing comprehensive whole person-oriented care for a defined population of patients over time (typically a primary care physician) - and then adding team members with the goal of leveraging their full scope of clinical skills to whole-person care as relevant to the needs of the population. Supplementation emphasizes everyone working "to the edge of their license," and preserving continuity with the core provider by making every effort to reduce the number of providers a patient has to be handed off to in a clinical encounter. We know that for some encounters, no handoffs are needed. We know that for patients with complex needs (with chronic conditions, for example), some handoffs appropriately occur in the clinical encounter in order to allow more time, for example, for health coaching or self-management support from a team member. ${ }^{143,144,145}$ These handoffs, however, must be warm (i.e., from the inception of team-based care, the goal must be to preserve relational continuity with the trusted core provider). This is the type of continuity supported in the literature as enhancing patient experience and outcomes. ${ }^{146,147,148}$ Team continuity, managed with this understanding, becomes an appropriate and positive extension of the relational continuity between a core provider and a patient; that is why the core measure of relational continuity remains at the provider level.

\footnotetext{
${ }^{137}$ Starfield, Leiyu, and Macinko (2005) op. cit.

${ }^{138}$ Ibid.

${ }^{139}$ Ibid

${ }^{140}$ Ibid.; Starfield, Barbara, J. Gervas, and D. Mangin (2012). "Clinical Care and Health Disparities," Annu Rev Public Health 33.

${ }^{141}$ There are also other support roles we have found to be absolutely essential in actualizing transformed models of care: business and financial process support, quality improvement/change management facilitation, and IM/IT evolution and support. These roles are sometimes combined, as in Taber where the business manager also possessed expert knowledge of IM/IT. The value of these roles in supporting transformed models of care cannot be overstated.

${ }^{142}$ Mark Murray of (Mark Murray and Associates) confirmed in a personal emailed communication February 21, 2013.

${ }^{143}$ Browne (2012) op. cit.

${ }^{144}$ Greb, Stefan. et al. (2009). "Co-ordination and Management of Chronic Conditions in Europe: the Role of Primary Care - Position Paper of the European Forum for Primary Care," Quality in Primary Care 17(1).

${ }^{145}$ Moran, Katherine et al. (2011). "Exploring the Cost and Clinical Outcomes of Integrating the Registered NurseCertified Diabetes Educator Into the Patient-Centered Medical Home," The Diabetes Educator 37(6).

${ }^{146}$ Haggerty et al. (2008) op. cit.

${ }^{147}$ Liss, David T. et al. (2011). "Patient-Reported Care Coordination: Associations with Primary Care Continuity and Specialty Care Use," Annals of Family Medicine 9(4).

${ }^{148}$ Turner, David et al. (2007). "Do Patients Value Continuity of Care in General Practice? An Investigation Using Stated Preference Discrete Choice Experiments," Journal of Health Services Research \& Policy 12(3).
} 
On the other hand, we have found that substitution of one provider for another is typically driven by thinking that can lead to fragmentation of care and reduced continuity. As primary care physician participants in our recent research in Taber reflected on the nature of their practice prior to engaging in service redesign, they described a chaotic and frustrating world of work; one participant noted "we had to do something...we didn't know what, but we knew there had to be a better way; we were dying." When a provider is at that point, it is tempting to believe that the something is to break down the work into manageable pieces (carve it up) and get someone else to do it (substitute), as soon as possible. The first thought is not likely to be "I have to radically rethink how I practice and redesign the entire process of care." Substitution thinking is also fed by the a priori basket-of-service approach taken in primary care reform initiatives in Alberta. When artificial divisions are created between different types of care such as preventive care, health-promoting care, chronic disease management support, and care that is more acute and episodic, it invites the mistaken assumption that these different types of care can be carved out of a patient's care requirements and assigned across multiple different team members. People don't think about, or experience their health-care needs that way. Patients with chronic illnesses have exacerbations of those illnesses, and also experience acute episodes of other unrelated illnesses, and preventive care should overlay all care. ${ }^{149}$

Another factor driving carved-up care is the use of clinical decision-support tools and guidelines that are constructed around a single disease, or a single provider. Indeed, as the PCN initiative rolled out across Alberta, the resources to support a transformed approach to practice were mainly developed under the auspices of the AMA (i.e., the Towards Optimized Practice program) - not surprisingly with a focus on the physician, rather than on how collaborative team-based practice could unfold. A key priority must be for evidence-informed and integrated decision-support tools to support continuous and comprehensive team-based care for individuals living with multiple chronic conditions and risk factors. Progress on care guidelines that are useful across providers has been made in some areas. ${ }^{150}$ Such integration is best supported with an EMR that can pull information to the point of care for an individual patient, and is acted on by a team that has the goal and requisite skills to assess and respond to the big picture, leveraging each contact to address broadly conceived priorities in care.

One final point on the notion of supplementation vs. substitution: substitution-thinking drives fractious politics as much as it drives fragmented care. Nowhere is this more clearly demonstrated than in the discussions around the added value of nurse practitioners (NPs) to the primary care team. Too often, we see this framed as an either-or (substitution) debate, instead of a useful discussion of the tremendous value of adding an NP team member whose skill set can be maximally leveraged to greatly increase the reach of high-quality and satisfying primary care $^{151,152}$ to a larger population. The evidence further demonstrates that outcomes are improved for complex patients and those with chronic disease when NPs are included in the provision of

\footnotetext{
${ }^{149}$ Murray, Marc (2012). "Critique of the Teamlet Model."

${ }^{150}$ Goldman, Joanne et al. (2010). "Interprofessional Primary Care Protocols: A Strategy to Promote an Evidence-Based Approach to Teamwork and the Delivery of Care," J Interprof Care 24(6).

${ }^{151}$ Browne (2012) op. cit.

${ }^{152}$ Keleher, Helen et al. (2009). "Systematic Review of the Effectiveness of Primary Care Nursing," Int J Nurs Pract 15(1).
} 
care. ${ }^{153,154}$ The full scopes of practice of all team members, NPs, physicians and others will intersect at different points in the provision of comprehensive primary care, and there are synergies to be gained when we keep our eye on the right ball: comprehensive, whole-person care that is planned to meet the needs of a defined population. The politics pitting professions against one another can only further stall productive discussions of primary care reform in Alberta.

\section{MOVING FORWARD IN ALBERTA: PAYMENT REDESIGN}

It has been our experience that discussions in Alberta around primary care reform tend to avoid the payment issue, particularly as it relates to physicians. Increasingly, however, we hear primary care physicians speaking up about some of the problems created by current payment mechanisms. ${ }^{155}$ This tells us that the time may be right to take a hard look at how payment serves to align incentives in our system. For this reason, we spend a bit more time reviewing the literature, and summarizing lessons we may be able to take from the work of others. We wish to emphasize that thoughtful payment reform is only one aspect of a system-wide transformation that needs to occur in reorienting our health-care system around high-quality primary care. We are also aware that professionals who choose to work in primary care do so for many reasons that go well beyond the money, so in spending more time here we do not wish to suggest otherwise. Payment reform, however, is crucial to consider in its ability to enable and incentivize teamwork, continuity of care, and comprehensive care. ${ }^{156,157,158,159}$

It is true that there is now a good deal of discussion in the literature regarding reformed payment or reimbursement approaches to primary care, particularly as related to physicians. How the core primary care provider is paid must reflect the goals, attributes and characteristics of a good primary care system. ${ }^{161,162}$ Fee-for-service (FFS) payment incentivizes episodic, problem-oriented care, and also requires the physician to see the whites of the patient's eyes in order for a visit to be reimbursed, even if the high-value care needed for that visit is best

\footnotetext{
${ }^{153}$ Jackson et al. (2011) op. cit.

${ }^{154}$ Russell, Grant M. et al. (2009). "Managing Chronic Disease in Ontario Primary Care: the Impact of Organizational Factors," Ann Fam Med 7(4).

${ }^{155}$ This was brought home powerfully by Dr. Rick Spooner, speaking on patient-centred care at the tri-professional conference in Banff, AB, May 24-26, 2012. His comment: "fee for service is the natural enemy of team-based care."

${ }^{156}$ Wranik, Dominika W. and Martine Durier-Copp (2010). "Physician Remuneration Methods for Family Physicians in Canada: Expected Outcomes and Lessons Learned," Health Care Anal 18(1).

${ }^{157}$ Leger, Pierre Thomas (2011). "Physician Payment Mechanisms: An Overview of Policy Options for Canada."

${ }^{158}$ Margolius and Bodenheimer (2010) op. cit.

${ }^{159}$ Rosenthal, Thomas C. (2008). "The Medical Home: Growing Evidence to Support a New Approach to Primary Care," J Am Board Fam Med 21(5).

${ }^{160}$ Scott, A. et al. (2011). "The Effects of Financial Incentives on the Quality of Health Provided by Primary Care Physicians," The Cochrane Library 9.

${ }^{161}$ Leger (2011) op. cit.

${ }^{162}$ Goroll, Allan H. (2011). "Payment Reform to Support Lasting Practice Reform in Primary Care," Journal of Ambulatory Care Management 34(1).
} 
provided by another team member. Further, in a FFS model, the payment must cover all costs: overhead, staffing, etc. Therefore, the use of a team cuts directly into the profit margin. These attributes do not align with comprehensive, whole-person or team-based care. Add to this the reality that FFS payments are retrospective and based on the volume of care that has occurred, and it's hard to escape the observation that FFS constitutes a significant cost-driver that is hard to predict and even harder to control. It's pretty clear that FFS does not align incentives to achieve the attributes we have outlined in this paper, yet the majority of primary care physicians in Alberta are paid on a FFS basis. ${ }^{163}$

Other potential payment mechanisms include capitation, pay for performance, and salary. ${ }^{164}$ Capitation is a prospective form of payment where physicians are paid a fixed amount (possibly risk- adjusted) for the care of a population of patients based on a roster or panel of patients attached to that physician or practice. ${ }^{165}$ The physician is then contractually committed to providing primary care for that patient for a certain length of time with no additional income. There is, as a result, an incentive to keep the costs per patient low. This also incentivizes physicians to take actions to keep their patients healthy by promoting health and providing preventative care. Such an approach to payment can also encourage innovation in practice, in terms of how to efficiently address patient needs in innovative ways with the use of supplemental technologies such as email, texting, web portals, telephone care etc. ${ }^{166}$ Capitation, however, can also have several negative effects including incentives to select individuals who will likely require little care in the future, and the temptation to use more hospital and specialized services to shift care away from the practice. ${ }^{167}$ In an attempt to more helpfully align incentives, there is increasing exploration of the use of pay for performance $(\mathrm{P} 4 \mathrm{P})$ to provide targeted incentives to improve care for patients, and there are many different approaches. ${ }^{168,169}$ The evidence is quite mixed, however, on the influence on care outcomes, ${ }^{170}$ and some have noted that when P4P targets are constructed in isolation, they introduce some risk of unintended consequences such as drawing attention and resources away from some important practices that are not being rewarded, in favor of those that are (also known as suboptimization). ${ }^{171,172}$ For example, Campbell and colleagues noted a worsening in continuity measures for practices that were rewarded for improved access. ${ }^{173}$ Finally, salary payment -

\footnotetext{
163 "Practicing Medicine in Alberta, Canada," (2012). Government of Alberta.

${ }^{164}$ Leger (2011) op. cit.

${ }^{165}$ Ibid.

${ }^{166}$ Ibid.

${ }^{167}$ Ibid.

${ }^{168}$ Scott et al. (2011) op. cit.

${ }^{169}$ Wilson, Kimberly (2013). "Pay-for-Performance in Health Care: What can we Learn from International Experience?" Qual Manag Health Care 22(1).

${ }^{170}$ Ibid.

${ }^{171}$ Korda, Holly and Gloria N. Eldridge (2011). "How we can bend the cost of curve: Payment Incentives and Integrated Care Delivery: Levers for Health System Reform and Cost Containment," Inquiry (00469580) 48(4).

${ }^{172}$ Berenson, Robert C. and Eugene C. Rich (2010). "US Approaches to Physician Payment: the Deconstruction of Primary Care," J Gen Intern Med 25(6).

${ }^{173}$ Campbell, Stephen M. et al. (2009). "Effects of Pay for Performance on the Quality of Primary Care in England," The New England Journal of Medicine 361(4) p. 376.
} 
paying a fixed amount regularly for services provided - can be a good base approach that eliminates concerns about financial self-interest playing a role in delivery of care. It has been noted, however, that salaried approaches introduce the risk of lower productivity, and limit incentives to take responsibility for the problem at hand. As such, it may not send clear signals about desirable behavior, and may not be the best approach in and of itself in achieving the best patient outcomes. ${ }^{174,175,176}$

It quickly becomes clear that any single payment approach has its strengths and flaws, and when used in isolation, may incentivize behaviors that do not support the achievement of highquality primary care. One potential solution designed to offset the downsides of any particular payment scheme is the use of a blended payment system. Such systems typically include a prospective component (i.e., capitation payment) and a retrospective component (i.e., a reimbursement like a FFS payment). ${ }^{177}$ The combination of these two components may provide the right incentives for the type and quantity of care desired to meet the needs of a particular population. It has been noted, however, that such schemes work best in an environment of competition, which does not exist in the Canadian health-care system. The downsides of capitation could also be addressed by risk-adjusting capitation in a way that preferentially rewards the attachment of patients with high complexity - those for whom attachment would create the highest benefit from a system point of view. Additional approaches, like P4P or some version of reward for cost savings incurred when added to the mixed approach, can add some further incentive.

Some models of blended payment have been used in Ontario ${ }^{178}$ and could be trialed, evaluated and modified for Alberta. Although more study of these different approaches is needed ${ }^{179,180} \mathrm{a}$ few things are becoming clearer from the Ontario experience and research to date. There has been a significant year-over-year increase in spending related to primary care physician payment and new funding models, but in an observation that mirrors the Alberta experience, the associated accountabilities are described as weak at best. ${ }^{181}$ In the Ontario approach to primary care, remuneration of physicians is achieved through one of three blended models, ${ }^{182}$ and it seems they are making some progress in meeting the Ontario goals for primary care.

\footnotetext{
${ }^{174}$ Goroll (2011) op. cit. p. 33.

${ }^{175}$ Berenson and Rich (2010) op. cit. p. 616.

${ }^{176}$ In New Brunswick, where a number of family physicians are salaried, they are trying to address some of these issues by implementing a Salaried Physician Monitoring System to ensure that salaried physicians are supporting a certain number of patients in their practice by establishing accountability benchmarks. It is not understood if this system incentivizes lower use of emergency room and hospital resources, as this would need to be managed in a salaried environment. (reference from Lisa Halma June 28, 2013) (attached)

${ }^{177}$ Leger (2011) op. cit.

178 "Guide to Interdisciplinary Provider Compensation," (2012).

${ }^{179}$ Hurley, Jeremiah et al. (2011). "The Response of Ontario Primary Care Physicians to Pay-for-Performance Incentives," Center for Health Economics and Policy Analysis.

${ }^{180}$ Jaakkimainen, R. Liisa et al. (2011). "Did Changing Primary Care Delivery Models Change Performance? A Population-Based Study Using Health Administrative Data," BMC Fam Pract 12.

${ }^{181}$ Drummond, Don et al. (2012). "Commission on the Reform of Ontario's Public Services,” Ontario: Government of Ontario.

${ }^{182}$ See Appendix 2
} 
It has been noted, however, that these blended models are not aligned well with overall health system needs and require stronger systems of accountability. ${ }^{183}$ In general, these payment schemes blend capitation with FFS and incentive payments, and have been found to be more conducive to inter-professional team-based care than straight FFS remuneration. However, it has been noted that age and sex adjustments to capitation are not adequate in capturing variation in need. ${ }^{185,186}$ In fact, it has been observed that until risk adjustment is added to the capitation component of the payment model, physicians are not only unlikely to choose this route of reimbursement, but a higher risk is incurred of some high-needs patients going without care. ${ }^{187}$ In addition, the current approach to P4P incentives in Ontario has produced only modest, if any, impact on outcomes. ${ }^{188}$ For example, the incentive scheme includes a bonus for improved primary care access, but this bonus remains unaffected if enrolled patients access the emergency department for needed care.

Ontario also provides some lessons on how to improve upon their approach. In the 2012 report of the Commission on the Reform of Ontario's Public Services, ${ }^{189}$ it was recommended that primary care become a focal point in an integrated health system, with the primary performance goals being prevention and keeping people out of hospitals. The authors further suggest that as a basic frame for payment, a blend of salary/capitation and FFS for providers be implemented in a rostered approach across disciplines. The report authors suggest the right balance to be about 70 per cent salary/capitation and 30 per cent FFS. ${ }^{190}$ They also recommended that any additional incentive payments be linked to positive health outcomes that are linked to strategic targets, including targets related to system utilization (such as emergency department use). Researchers in Quebec are also looking to Ontario as they seek to improve their approaches to physician payment. ${ }^{191}$ To date, Quebec has encouraged a move towards Family Medicine Groups (FMG) with enrollment of patients, but still largely based on a FFS model. ${ }^{192}$ Public funding has been added to the FMG model in a manner similar to the PCN annual envelope approach implemented in Alberta. In addition, physicians working in the FMG receive a capitation payment for each enrolled patient, as well as additional payments for the provision of 24- hour phone access, and for time spent on call.

\footnotetext{
${ }^{183}$ Hutchison, Brian and Ricahrd Glazier (2013) “Ontario's Primary Care Reforms have Transformed the Local Care Landscape, but a Plan is Needed for Ongoing Improvement," Health Aff (Millwood) 32(4). 
Some other more extensively studied and supported payment approaches coming out of the US include the Geisinger's ProvenHealth Navigator compensation model using a value-based reimbursement approach, an approach that combines FFS payments to reward practices for improving access to care with P4P for quality outcomes. This model emphasizes the bundling of indicators to reduce the risk of sub-optimization, an approach that has also been found by others to be effective in improving quality of care. ${ }^{193}$ The Geisinger approach also includes physician and practice transformation stipends to support new activities, and an incentive built on the notion of shared savings based on the practice receiving back a proportion of savings incurred, paid on the percentage of quality targets achieved. ${ }^{194,195}$

Unfortunately, there is very little evidence around potential remuneration or incentive schemes to better support team-based care, with most health-care providers other than physicians paid a salary for their work. In any reform of payment systems, we assert that incentives need to be aligned such that health-care teams are supported to serve a patient roster based on the needs of that roster. Providers must be supported and expected to function to their full scope of practice to meet the needs of the population they are serving. Position descriptions and expectations must be clearly outlined, performance goals must align with the service goals of the practice, and payment should be commensurate with other colleagues in the health-care system in that jurisdiction. Incentive payments should be paid to the practice rather than to one provider, and payments to health professionals contributing to improving the quality of care should be commensurate to their skill and effort - i.e., any pay for performance should go to all healthcare team members involved in the care of the patient population, and this pay should be consistent with their role in that care. It would be important to communicate these expectations as part of the hiring process, including clear expectations around role expectations and payment structures. ${ }^{196,197}$ Further, what little guidance is provided in the literature around team remuneration does not address the complexities added when team members employed by local health service providers are integrated into primary care teams, nor does it assist us in navigating the implications of sharing staff between unionized and non-unionized environments. These remain open questions for further deliberation.

Certainly, there have been numerous other payment mechanisms around primary care that have been added to basic physician FFS in Alberta: most notably PCN capitated payments, (where it was suggested, but not required that the additional money be directed to support teams); there were also additional payments for performance and diligence which were experimented with, but didn't progress very far. It must be said, however, that although these strategies have added to the available sources of income for physicians, they have not necessarily been structured to incentivize behavior that supports the principles of achieving a high-performing primary care system. Where many of these principles have been enacted has been within the context of "Alternative Relationship Plans" (ARPs). Alberta Health defines an ARP as an arrangement

193 de Bakker, Dinny H. et al. (2012). "Early Results from Adoption of Bundled Payment for Diabetes Care in the Netherlands Show Improvement in Care Coordination," Health Aff (Millwood) 31(2).

${ }^{194}$ Maeng et al. (2012) op. cit.

${ }^{195}$ Gilfillan et al. (2010) op. cit.

${ }^{196}$ Campbell, Stephen M. et al. (2010). "Implementing Pay-for-Performance in Australian Primary Care: Lessons from the United Kingdom and the United States," MJA 193(7).

${ }^{197}$ Scott, A. et al. (2011). "Financial Incentives and the Quality of Primary Health Care in Australia," Australian Primary Healthcare Research Institute. 
that compensates physicians for providing a set of clinical services to a target population. ${ }^{198}$ These models, although accounting for less than 10 per cent of family physicians in the province, ${ }^{199}$ have proven quite successful in terms of supporting team-based, comprehensive and whole person-focused primary care. We are familiar with two primary care environments where ARPs have been very successfully enacted. ${ }^{200}$ This leads us to suggest that at the very least, ARPs are Alberta innovations that are at least worth evaluating more fully - and possibly expanding.

Based on the evidence, it is clear that no model of blended payment has been proposed that is without weaknesses. ${ }^{201}$ We suggest, however, that the evidence points to a blended payment model that combines appropriately risk-adjusted capitation (to incentivize whole-person and team-oriented care, and mitigate the costs of caring for complex patients) with FFS (to incentivize access and care of unattached persons), and the possible addition of a payment incentive to teams based on bundled indicators that are directly related to the core attributes of high-performing primary care. For example, solid measures exist for the core attributes of access, continuity and patient experience. ${ }^{202}$ It may be valuable to bundle these indicators with selected chronic disease prevention and management indicators (that are relevant to the population served) as weighted criteria, and then track them as a bundle to arrive at a composite score (adjusted for panel/roster size) that could then be used to determine supplementary payment (up to a maximum amount). Finally, and in alignment with our vision of a system oriented around the primary care hub, we urge consideration of building in incentives that encourage all sectors to view the system as a whole in terms of appropriate utilization and high-quality care. As examples: primary care could be incentivized to take accountability for reducing the use of emergency departments for needs that could better be met in primary care; hospitals could be incentivized to ensure seamless connections with the primary care sector; and specialty care could be incentivized to be responsive to referrals emerging from primary care.

\footnotetext{
${ }^{198}$ http://www.health.alberta.ca/professionals/ARP-Clinical.html: accessed January 2013.

${ }^{199}$ Wranik and Durier-Copp (2010) op. cit.

${ }^{200}$ The Taber Clinic, and the Crowfoot Village Family Practice in Calgary are remunerated within a capitation-based Alternate Relationship Plan in the province of Alberta. In Crowfoot, patients are formally rostered to the practice, and committed to a continuous relationship with the physician and team by signing a contract with that patient when the patient joins their roster; in Taber an informal geographic roster is established. These ARPs differ based on location and the needs and characteristics of the populations served. Physicians also receive fee-for-service payments for services to unrostered patients and for services not regularly offered as part of the agreement. Both practices leverage the value of team-based care: they are able to provide superior and more comprehensive care, improve the quality of work life for the core primary care providers, and also bring more money into the practice because of the ability to support a larger roster. Additional money brought to the practice allows them to enhance their provider teams; PCN funds have also helped support this. These practices are providing comprehensive whole-person care to their rostered population, built in as an expectation within the ARP; both practices are also "negated," or penalized in different ways for patients seeking care elsewhere. Both practices find that preserving continuity enhances patient satisfaction and coordinated care, and are adamant that the ARP is a critical enabler of team-based, coordinated, proactive, comprehensive, whole person-oriented care - although there has been limited pre/post evaluation of the payment models or a whole-system look at the impact on costs and utilization to the overall system. Both have, however, showed improved outcomes and improved preventative care for their populations. Taber in particular has demonstrated and maintained impressive reductions in the use of the emergency department for their rostered population. We know that other practices in Alberta are interested in pursuing ARPs, and we also know that the Taber and Crowfoot models are clearly on the right track in terms of the incentives they create.

${ }^{201}$ Scott et al. (2011) op. cit.

${ }^{202}$ See Appendix 1.
} 
In summary, although there are certainly gaps in the evidence, we believe that there is enough evidence and experience to guide us in building and trialing a blended payment model, keeping in mind the need for robust evaluation and ongoing measurement of the ability of any system to influence the achievement of desired outcomes. We believe that the following principles are useful in discussions of payment reform:

- A rostered population.

- Payment innovation that incentivizes a balanced achievement of indicators and mitigates known risks (e.g., bundling; negation for loss of continuity).

- Incentive payments paid to the practice, and payments to health professionals involved in improving quality of care structured and administered equitably with respect to skill and effort.

- Adjustment of capitation payments based on age, sex, and co-morbidities/complexity.

- Incentives for improvements in quality as well as achievement of levels of quality.

- An expectation of system improvements as a result of funds directed to primary care: namely reduced hospitalization, reduced specialist care, and reduced emergency room/urgent care utilization.

- A payment scheme that is simple and straightforward to administer.

- A full discussion among stakeholders of potential unintended consequences and risks.

\section{CONCLUSION: ACCOUNTABILITY FOR ACTION}

It goes without saying that transforming the health system around primary care will take courage and an unwavering commitment to the vision at all levels in Alberta. It will require clearly defined objectives and associated accountabilities, and requirements to work together to live up to them. If collectively we can't find the courage to do that, we will continue to meander, and for a great deal of cost. Reform cannot be about any one profession, and we note the courage already shown by a provincial government willing to separate primary care reform discussions from physician contract negotiations. It has been our observation that up to this point, the dominant values in place in primary care reform in Alberta have indeed been provider-centric. In particular, the core value of professional autonomy often seems to take centre stage in discussions of how primary care needs to reform. The single-mindedness with which all disciplines and professional associations protect and promote professional autonomy has nurtured timidity in setting out clear provincial expectations about meeting the health needs of a population, has perpetuated inter-professional sensitivities about how team-based care and clinical governance are enacted, and has encouraged an approach to care that focuses accountability on one patient, and one care episode at a time. Achieving the vision requires a whole-population, whole person-centric value orientation. That means finding ways to remove the barriers between citizens and primary care providers, and between different care providers. It means broadening accountabilities beyond meeting the presenting need of one patient at time, and increasing the ability of primary care to actually influence overall population health - to actually make a difference. If we have learned one thing in studying the Taber experience, it is this: creating the opportunity to actually make a visible difference is the fuel 
for continuous improvement, and the glue of shared accountability for whole-person, wholepopulation care. Further, reform cannot be about any one model. In fact, it can't only be about one part of the system - it must be about the whole system changing its orientation to a primary health-care approach, starting with organizing health care around the primary care hub. Although government's more recent inclusive language around FCCs as a supplementary approach alongside PCNs reflects recognition that getting into a models debate is unproductive, it's important to remember that sometimes inclusive approaches can take us all down the road to vague objectives and flexible accountabilities. Progress will be hampered by the absence of a clear and consistent set of expectations around accountability.

It is our hope that the thinking in this paper is somehow useful in promoting continued dialogue about, and focused action on, moving the primary care agenda forward in Alberta. We believe that fundamentally, it comes down to a series of accountabilities for taking the necessary steps toward whole-system reform around primary care. We believe that there are key accountabilities that reside at multiple levels: with the public, government, the health system, the primary care practice, and the individual patient/family. We have summarized these in Table 3, and organized them by what we have identified as the essential attributes of a highperforming, primary care-oriented health system. Not included in the table are other accountabilities that also merit consideration - e.g., the responsibility of health professional associations to support their members in moving beyond provider-centric values of autonomy, in favor of values that support shared accountability for meeting the health needs of populations. Indeed, we believe that in many cases, practitioners at the front end of primary care are far ahead of their professional bodies or collective bargaining associations in terms of promoting collaboration and team-based care. Professional licensing bodies need to continue exploring how to regulate their members as part of interdisciplinary teams, and how best to support their members to enact full scope of practice in the delivery of comprehensive primary care.

Collectively, we must continue with principled innovation and commit to robust evaluation; all the answers are not in the published evidence. Progress requires that we all have the courage to ask, and eventually answer, difficult questions. Why has it been acceptable to succumb to substitution-thinking when the discussion shifts to organizing team-based primary care services in remote parts of the province? How is patient choice honoured while pursuing a focus on rostering? How is meaningful engagement of the public ensured in primary care reform? What is the right size for a defined population around which to integrate services? What are the implications for teams and service integration related to unions? How does the devolution of governance and accountability for local health services around primary care mesh with the more centralized Alberta Health Services structure? Perhaps most contentious of all: is participation in primary care reform optional? We do not pretend to have the answers to these questions. But to paraphrase the 20th century science historian Jacob Bronowski, asking impertinent questions is often the best way to arrive at pertinent answers. 
TABLE 3: ATTRIBUTES* AND ENABLERS AND ASSOCIATED ACCOUNTABILITIES

\begin{tabular}{|c|c|c|c|c|}
\hline $\begin{array}{l}\text { Attributes*/ } \\
\text { Enablers }\end{array}$ & Government & $\begin{array}{l}\text { General Public/ } \\
\text { Patients }\end{array}$ & Health System & Primary Care Teams \\
\hline Access* & $\begin{array}{l}\text { - Require } 24 / 7 \text { advanced } \\
\text { access to primary care team } \\
\text { for defined population. } \\
\text { - Remove barriers to e- } \\
\text { communication with patients. } \\
\text { - Ensure that issues around } \\
\text { access to complete primary } \\
\text { care services for remote and } \\
\text { marginalized populations are } \\
\text { broadly discussed and } \\
\text { equitably addressed. }\end{array}$ & $\begin{array}{l}\text { - Ensure issues of } \\
\text { access and equity } \\
\text { of access across } \\
\text { the population are } \\
\text { raised and } \\
\text { addressed. }\end{array}$ & $\begin{array}{l}\text { - Measure and monitor } \\
\text { service delays between } \\
\text { primary, specialty and } \\
\text { acute care services. } \\
\text { - Ongoing commitment to } \\
\text { improve system flow. }\end{array}$ & $\begin{array}{l}\text { - Expand access to meet } \\
\text { population needs } 24 / 7 . \\
\text { - Collaborate with other } \\
\text { primary-level service } \\
\text { providers to enhance access. } \\
\text { - Emphasize advanced access, } \\
\text { and measure it. } \\
\text { - Ensure a balance of access } \\
\text { with the preservation of } \\
\text { provider continuity. }\end{array}$ \\
\hline $\begin{array}{l}\text { Population- } \\
\text { focused } \\
\text { accountability* }\end{array}$ & $\begin{array}{l}\text { - Require evidence to support } \\
\text { services proposed for } \\
\text { population. } \\
\text { - Develop and mandate a } \\
\text { clear and consistent } \\
\text { provincial accountability } \\
\text { framework. } \\
\text { - Require public reporting on } \\
\text { key indicators. } \\
\text { - Support community efforts to } \\
\text { gather and assemble data on } \\
\text { local populations and } \\
\text { support the identification of } \\
\text { population-level risk factors. } \\
\text { - Support primary care } \\
\text { practice efforts to establish } \\
\text { formal rosters of unique } \\
\text { citizens. }\end{array}$ & $\begin{array}{l}\text { - Engagement in } \\
\text { efforts to identify } \\
\text { community health } \\
\text { needs. } \\
\text { - Establish and } \\
\text { maintain a } \\
\text { connection with a } \\
\text { primary care } \\
\text { provider team. } \\
\text { - Take ownership/ } \\
\text { accountability for } \\
\text { personal health and } \\
\text { partnership in care. }\end{array}$ & $\begin{array}{l}\text { - Support integration of all } \\
\text { services with primary } \\
\text { care around needs of } \\
\text { population. } \\
\text { - Emphasize patient- } \\
\text { /family-centered culture } \\
\text { of care. } \\
\text { - Create and sustain a } \\
\text { culture of shared } \\
\text { accountability for } \\
\text { excellence based on a } \\
\text { shared vision and } \\
\text { purpose. } \\
\text { - Share data with primary } \\
\text { care teams to proactively } \\
\text { case find, e.g., identify } \\
\text { population clusters at } \\
\text { high risk for health } \\
\text { problems. }\end{array}$ & $\begin{array}{l}\text { - Institute formal rostering with } \\
\text { patient confirmation. } \\
\text { - Take accountability for the } \\
\text { defined population. } \\
\text { - Gather information on } \\
\text { practice population and } \\
\text { identify population risks. } \\
\text { - Emphasize whole-person } \\
\text { focus of care. } \\
\text { - Create and sustain a culture } \\
\text { of shared accountability } \\
\text { based on a shared } \\
\text { vision/purpose. } \\
\text { - Identify patients that would } \\
\text { benefit from complex case } \\
\text { management. } \\
\text { - Share data with broader } \\
\text { health system to proactively } \\
\text { case find, e.g., identify } \\
\text { population clusters at high } \\
\text { risk for health problems. }\end{array}$ \\
\hline $\begin{array}{l}\text { Patient } \\
\text { engagement* }\end{array}$ & $\begin{array}{l}\text { - Require formal rostering. } \\
\text { - Require the measurement of } \\
\text { patient experience on all } \\
\text { core attributes, using } \\
\text { evidence-based instruments. }\end{array}$ & $\begin{array}{l}\text { - Establish and } \\
\text { maintain a } \\
\text { connection with a } \\
\text { primary care } \\
\text { provider team. } \\
\text { - Take ownership and } \\
\text { accountability for } \\
\text { personal health and } \\
\text { participation as an } \\
\text { active partner in } \\
\text { care. } \\
\text { - Ensure team knows } \\
\text { how to get in touch. } \\
\text { - Provide feedback } \\
\text { on all core } \\
\text { attributes. }\end{array}$ & $\begin{array}{l}\text { - Emphasize patient- and } \\
\text { family-centeredness and } \\
\text { welcome feedback. } \\
\text { - Engage patients and } \\
\text { families in quality } \\
\text { improvement activities. }\end{array}$ & $\begin{array}{l}\text { - Support innovative patient- } \\
\text { led strategies such as patient } \\
\text { support/education groups. } \\
\text { - Expect and support active } \\
\text { patient participation in care. }\end{array}$ \\
\hline Continuity* & $\begin{array}{l}\text { - Create the expectation that } \\
\text { Albertans need to roster with } \\
\text { a single primary care team. } \\
\text { - Monitor rostering provincially } \\
\text { to minimize duplication of } \\
\text { attachment to teams. }\end{array}$ & $\begin{array}{l}\text { - Commit to an } \\
\text { ongoing relationship } \\
\text { with the core team. } \\
\text { - Commit to being a } \\
\text { part of the team } \\
\text { and to } \\
\text { communicate } \\
\text { factors that may } \\
\text { impact continuity. }\end{array}$ & $\begin{array}{l}\text { - As much as possible, } \\
\text { align service provider } \\
\text { teams with the primary } \\
\text { care hub, to facilitate } \\
\text { communication and } \\
\text { relationships across the } \\
\text { continuum around a } \\
\text { defined population. }\end{array}$ & $\begin{array}{l}\text { - Commit to whole person- } \\
\text { focused care. } \\
\text { - Minimize handoffs, and when } \\
\text { they are necessary, ensure } \\
\text { they are warm. } \\
\text { - Emphasize relational } \\
\text { continuity, and measure it. }\end{array}$ \\
\hline
\end{tabular}


TABLE 3: ATTRIBUTES* AND ENABLERS AND ASSOCIATED ACCOUNTABILITIES (cont'd)

\begin{tabular}{|c|c|c|c|c|}
\hline $\begin{array}{l}\text { Attributes*/ } \\
\text { Enablers }\end{array}$ & Government & $\begin{array}{l}\text { General Public/ } \\
\text { Patients }\end{array}$ & Health System & Primary Care Teams \\
\hline $\begin{array}{l}\text { Coordination } \\
\text { and service } \\
\text { integration* }\end{array}$ & $\begin{array}{l}\text { - Set out a clear vision, with } \\
\text { clear objectives for primary } \\
\text { care reform. } \\
\text { - Policy innovation: place } \\
\text { primary care at the centre of } \\
\text { the system (strategic policy } \\
\text { decisions that reinforce } \\
\text { structures/ } \\
\text { governance/funding } \\
\text { allocation around primary } \\
\text { care). } \\
\text { - Require evidence of initial } \\
\text { and ongoing work to } \\
\text { integrate with existing health } \\
\text { services, identifying areas of } \\
\text { duplication and primary care } \\
\text { gaps. } \\
\text { - Identify and remove barriers } \\
\text { to the coordination of care } \\
\text { across sectors. } \\
\text { - Expect and support enablers } \\
\text { of integration IM/IT; } \\
\text { collaborative, cross- } \\
\text { continuum quality } \\
\text { improvement processes; } \\
\text { community efforts to identify } \\
\text { and integrate existing } \\
\text { primary-level services. }\end{array}$ & $\begin{array}{l}\text { - Commit to } \\
\text { supporting } \\
\text { coordination } \\
\text { efforts. }\end{array}$ & $\begin{array}{l}\text { - Focus on primary care } \\
\text { as the hub and realign } \\
\text { other service programs } \\
\text { around primary care. } \\
\text { - Shift focus in SCNs to } \\
\text { integration and } \\
\text { coordination with } \\
\text { primary care. } \\
\text { - Pull to primary: make } \\
\text { decisions that reflect } \\
\text { that the whole system } \\
\text { needs to be primary } \\
\text { care-oriented. } \\
\text { - Removal of barriers to } \\
\text { shared information and } \\
\text { communication that } \\
\text { support shared } \\
\text { caseloads with other } \\
\text { primary-level service } \\
\text { providers (e.g., } \\
\text { integrated rosters with } \\
\text { extended team } \\
\text { members in CDM, } \\
\text { addictions and mental } \\
\text { health, public health, } \\
\text { system- level case } \\
\text { managers in home } \\
\text { care). } \\
\text { - Participate in quality } \\
\text { improvement in } \\
\text { collaboration with other } \\
\text { primary care-level } \\
\text { providers and all } \\
\text { sectors of care. } \\
\text { - Ensure coordination } \\
\text { across the acute } \\
\text { care/primary care } \\
\text { divide. }\end{array}$ & $\begin{array}{l}\text { - Participate in governance } \\
\text { innovation that supports } \\
\text { shared governance around } \\
\text { primary care at the provincial } \\
\text { and local levels. } \\
\text { - Enable shared clinical } \\
\text { decision-making. } \\
\text { - Establish core and extended } \\
\text { teams based on population } \\
\text { health needs. } \\
\text { - Integrate with other primary- } \\
\text { level health care services. } \\
\text { - Coordination through } \\
\text { system-level case } \\
\text { management with } \\
\text { community service agencies } \\
\text { for complex populations. } \\
\text { - Commit to mechanisms of } \\
\text { coordination with specialty } \\
\text { and acute care. } \\
\text { - Participate in models of } \\
\text { shared care with specialty } \\
\text { practices. } \\
\text { - Create the demand for and } \\
\text { participate in the } \\
\text { development of decision- } \\
\text { support tools that are } \\
\text { integrated across providers } \\
\text { and conditions. } \\
\text { - Collaborate in quality } \\
\text { improvement with other } \\
\text { sectors. }\end{array}$ \\
\hline $\begin{array}{l}\text { Comprehensive } \\
\text { whole-person } \\
\text { care* }\end{array}$ & & $\begin{array}{l}\text { - Engage positively } \\
\text { with the primary } \\
\text { care team around } \\
\text { proactive, whole- } \\
\text { person care. } \\
\text { - Commit to being a } \\
\text { part of the team. } \\
\text { - Take the initiative } \\
\text { to communicate } \\
\text { care needs to } \\
\text { team. }\end{array}$ & $\begin{array}{l}\text { - Commit to capacity- } \\
\text { building in primary } \\
\text { care to support the } \\
\text { pull to primary. } \\
\text { - Support collaboration } \\
\text { between primary and } \\
\text { secondary care to } \\
\text { develop provincial } \\
\text { primary-level clinical } \\
\text { decision supports that } \\
\text { are not discipline- } \\
\text { specific and not single } \\
\text { disease-specific. }\end{array}$ & $\begin{array}{l}\text { - Leverage every contact with } \\
\text { a person as an opportunity } \\
\text { to improve health. } \\
\text { - Take accountability to initiate } \\
\text { preventive care as } \\
\text { recommended by guidelines, } \\
\text { even if that is not the } \\
\text { purpose of the visit. } \\
\text { - Ensure that all care, } \\
\text { including handoff for } \\
\text { complex care/case } \\
\text { management takes a whole- } \\
\text { person focus (resist carved- } \\
\text { out care and substitution- } \\
\text { thinking). } \\
\text { - Commit to } \\
\text { comprehensiveness, and } \\
\text { measure it. }\end{array}$ \\
\hline
\end{tabular}


TABLE 3: ATTRIBUTES* AND ENABLERS AND ASSOCIATED ACCOUNTABILITIES (cont'd)

\begin{tabular}{|c|c|c|c|c|}
\hline $\begin{array}{l}\text { Attributes*/ } \\
\text { Enablers }\end{array}$ & Government & $\begin{array}{l}\text { General Public/ } \\
\text { Patients }\end{array}$ & Health System & Primary Care Teams \\
\hline \begin{tabular}{|l} 
Team-based \\
care*
\end{tabular} & $\begin{array}{l}\text { - Investigate and support } \\
\text { health human resource } \\
\text { solutions and other } \\
\text { resources to support team } \\
\text { members being shared } \\
\text { across sectors (co-location } \\
\text { where feasible; electronic } \\
\text { communication supports } \\
\text { where team members are } \\
\text { virtual). } \\
\text { - Requirements in health-care } \\
\text { educational programs for } \\
\text { inter-professional education. }\end{array}$ & $\begin{array}{l}\text { - Commit to being a } \\
\text { part of a primary } \\
\text { care team. } \\
\text { - Acknowledge } \\
\text { commitment and } \\
\text { shared } \\
\text { responsibilities } \\
\text { (where feasible). }\end{array}$ & $\begin{array}{l}\text { - Commit to capacity } \\
\text { building in primary care } \\
\text { to support the pull to } \\
\text { primary. } \\
\text { - Develop program team } \\
\text { members in health } \\
\text { coaching; case } \\
\text { management; CD self- } \\
\text { management support. } \\
\text { - Expect and facilitate } \\
\text { integration of team } \\
\text { responsibilities to } \\
\text { support primary care. } \\
\text { - Expect measurement of } \\
\text { indicators developed to } \\
\text { monitor service } \\
\text { connections with primary } \\
\text { care. }\end{array}$ & $\begin{array}{l}\text { - Establish and confirm } \\
\text { connection with patient, and } \\
\text { outline shared } \\
\text { accountabilities. } \\
\text { - Commit to whole-person care } \\
\text { and resist substitution- } \\
\text { thinking. } \\
\text { - Frame team broadly to } \\
\text { include extended team. } \\
\text { - Develop team in basic health } \\
\text { coaching; complex case } \\
\text { management; chronic } \\
\text { disease self-management. } \\
\text { - Measure team effectiveness } \\
\text { and progress. } \\
\text { - Ongoing team development } \\
\text { in continuous quality } \\
\text { improvement. } \\
\text { - Expect full scope of practice. } \\
\text { - Create and sustain a culture } \\
\text { of shared accountability. } \\
\text { - Engage in clinical leadership } \\
\text { that supports a team } \\
\text { approach. }\end{array}$ \\
\hline \begin{tabular}{|l} 
Quality \\
Improvement
\end{tabular} & $\begin{array}{l}\text { - Establish core indicators for } \\
\text { primary care and require } \\
\text { consistent reporting on them. } \\
\text { - Enhance the capacity and } \\
\text { support for system-wide, } \\
\text { ongoing quality improvement. } \\
\text { - Expect/monitor system } \\
\text { improvements in health-care } \\
\text { utilization as a result of } \\
\text { primary care reform. } \\
\text { - Address barriers to system- } \\
\text { wide quality improvement. } \\
\text { - Monitor and provide } \\
\text { feedback re: primary care } \\
\text { attachment across Alberta. }\end{array}$ & $\begin{array}{l}\text { - Participate in } \\
\text { quality improvement } \\
\text { activities at the } \\
\text { local level. }\end{array}$ & $\begin{array}{l}\text { - Commit to continuous } \\
\text { quality improvement } \\
\text { across all programs } \\
\text { consistent with the } \\
\text { principles of AlM. } \\
\text { - Expect and facilitate staff } \\
\text { participation in system- } \\
\text { wide quality } \\
\text { improvement and flow } \\
\text { initiatives. } \\
\text { - Monitor system quality } \\
\text { indicators in health } \\
\text { service areas. }\end{array}$ & $\begin{array}{l}\text { - Ongoing practice-level } \\
\text { measurement of } \\
\text { access/continuity/outcomes } \\
\text { for population served. } \\
\text { - Participate in system flow } \\
\text { initiatives to facilitate system } \\
\text { redesign. } \\
\text { - Change management and } \\
\text { facilitation -participation in } \\
\text { AlM. } \\
\text { - Support innovation by sharing } \\
\text { learning across sectors. }\end{array}$ \\
\hline Technology & $\begin{array}{l}\text { - Informational infrastructure } \\
\text { and in-practice support for: } \\
\text { integrated, inter-operable } \\
\text { EMR development. } \\
\text { - Data support: update data } \\
\text { infrastructure to be able to } \\
\text { provide timely community } \\
\text { and primary care-level data. } \\
\text { - Remove barriers to use of } \\
\text { additional communication } \\
\text { technologies to connect with } \\
\text { patients. } \\
\text { - Collect and share data to } \\
\text { support seamless transitions } \\
\text { and information sharing } \\
\text { across the system. } \\
\text { - Engage in health technology } \\
\text { assessment that includes } \\
\text { consideration of how the } \\
\text { technology supports the } \\
\text { primary care level of service. }\end{array}$ & $\begin{array}{l}\text { Provide feedback, } \\
\text { input on } \\
\text { technological } \\
\text { innovations being } \\
\text { trialed, used in the } \\
\text { practice. }\end{array}$ & $\begin{array}{l}\text { - Use of technology to } \\
\text { enhance access for and } \\
\text { communication with } \\
\text { patients. } \\
\text { - Commit to collaborate } \\
\text { across primary care and } \\
\text { other sectors of care in } \\
\text { development of IM/IT } \\
\text { solutions that integrate } \\
\text { across the continuum. }\end{array}$ & $\begin{array}{l}\text { - Use technology to enhance } \\
\text { access and communication } \\
\text { with patients. } \\
\text { - Seek patient input and } \\
\text { feedback on technological } \\
\text { innovations. } \\
\text { - Incorporate technology not as } \\
\text { a solution, but as an enabler } \\
\text { of care processes supporting } \\
\text { the essential attributes. }\end{array}$ \\
\hline
\end{tabular}


TABLE 3: ATTRIBUTES* AND ENABLERS AND ASSOCIATED ACCOUNTABILITIES (cont'd)

\begin{tabular}{|c|c|c|c|c|}
\hline \begin{tabular}{|l|} 
Attributes*/ \\
Enablers
\end{tabular} & Government & $\begin{array}{l}\text { General Public/ } \\
\text { Patients }\end{array}$ & Health System & Primary Care Teams \\
\hline \begin{tabular}{|l} 
Payment/ \\
funding
\end{tabular} & $\begin{array}{l}\text { - Requirements for funding to } \\
\text { flow through entities that } \\
\text { emphasize shared } \\
\text { governance with community } \\
\text { involvement, not single } \\
\text { providers. } \\
\text { - Expanded capacity for ARPs } \\
\text { in primary care. } \\
\text { - Develop and evaluate models } \\
\text { of team-based pay-for- } \\
\text { performance. } \\
\text { - Restricted, targeted use of } \\
\text { FFS funding to create } \\
\text { appropriate incentives to } \\
\text { provide care in unexpected } \\
\text { situations, or in other } \\
\text { circumstances where } \\
\text { incentivizing volume of } \\
\text { service is appropriate. } \\
\text {-Link primary care innovation } \\
\text { funding to the provincial } \\
\text { accountability framework. } \\
\text { - Fund primary innovation } \\
\text { based on assessment of } \\
\text { health needs and gaps in } \\
\text { existing services. }\end{array}$ & & & $\begin{array}{l}\text { - Take appropriate measures to } \\
\text { minimize negation. } \\
\text { - Develop mechanisms to } \\
\text { recognize and reward team } \\
\text { efforts in improving quality of } \\
\text { care. }\end{array}$ \\
\hline $\begin{array}{l}\text { Shared } \\
\text { governance/ } \\
\text { engagement of } \\
\text { communities }\end{array}$ & $\begin{array}{l}\text { - Require mechanisms for } \\
\text { meaningful public input into } \\
\text { governance at provincial and } \\
\text { local levels. } \\
\text { - Require shared governance } \\
\text { across all sectors of care at } \\
\text { the provincial level. } \\
\text { - Initiate and support shared } \\
\text { governance innovation at } \\
\text { local levels for a defined } \\
\text { population. } \\
\text { - Expect participation in } \\
\text { models of shared governance } \\
\text { at provincial and local levels. }\end{array}$ & $\begin{array}{l}\text { - Awareness of and } \\
\text { participation in } \\
\text { health-system } \\
\text { governance at local } \\
\text { levels. } \\
\text { - Engagement in } \\
\text { efforts to identify } \\
\text { community health } \\
\text { needs. } \\
\text { - Providing input as } \\
\text { citizens into } \\
\text { creating } \\
\text { accountable and } \\
\text { equitable systems } \\
\text { that promote } \\
\text { health. }\end{array}$ & $\begin{array}{l}\text { - Participate in governance } \\
\text { innovation that supports } \\
\text { shared governance } \\
\text { around primary care at } \\
\text { the provincial and local } \\
\text { levels. } \\
\text { - Engage patients and } \\
\text { families in quality } \\
\text { improvement activities. }\end{array}$ & $\begin{array}{l}\text { - Participate in shared } \\
\text { governance around primary } \\
\text { care at the provincial and } \\
\text { local levels. } \\
\text { - Establish mechanisms to } \\
\text { identify and address health } \\
\text { and care needs of the } \\
\text { panel/roster as part of the } \\
\text { larger community. } \\
\text { - Commit to identifying and } \\
\text { addressing access for } \\
\text { marginalized populations. }\end{array}$ \\
\hline
\end{tabular}




\section{APPENDIX 1: ACCOUNTABILITY FRAMEWORK ${ }^{242}$}

\begin{tabular}{|c|c|c|c|c|}
\hline Objective & \begin{tabular}{|c|} 
Related \\
HQCA \\
Quality \\
Dimensions \\
\end{tabular} & $\begin{array}{c}\begin{array}{c}\text { Unit } \\
\text { of } \\
\text { Measure }\end{array} \\
\end{array}$ & $\begin{array}{l}\text { Indicator/Measure } \\
\text { Recommendations }\end{array}$ & $\begin{array}{l}\text { Rationale/ } \\
\text { Comments }\end{array}$ \\
\hline $\begin{array}{l}\text { ACCESS } \\
\text { All Albertans are } \\
\text { attached to a } \\
\text { single roster of } \\
\text { choice, and have } \\
\text { same-day, } 24 / 7 \\
\text { access to a } \\
\text { primary care } \\
\text { team. }\end{array}$ & Accessibility & $\begin{array}{l}\text { Entire } \\
\text { roster }\end{array}$ & $\begin{array}{l}\text { Time to third next available appointment } \\
\text { (This indicator measures the number of } \\
\text { calendar days to the next third appointment by } \\
\text { provider type). }{ }^{244}\end{array}$ & $\begin{array}{l}\text { This is based on a standardized } \\
\text { measure utilized in relation to the } \\
\text { principles of advanced access, and } \\
\text { is tracked in relation to all } \\
\text { appointment types for all patients. } \\
\text { The goal is same-day } \\
\text { appointments. }\end{array}$ \\
\hline $\begin{array}{l}\text { POPULATION } \\
\text { FOCUS } \\
\text { Primary care } \\
\text { services are } \\
\text { integrated around } \\
\text { the identified } \\
\text { health- care } \\
\text { needs of a } \\
\text { defined roster of } \\
\text { patients. }\end{array}$ & $\begin{array}{l}\text { Appropriateness; } \\
\text { efficiency }\end{array}$ & $\begin{array}{l}\text { Entire } \\
\text { roster; } \\
\text { care team }\end{array}$ & $\begin{array}{l}\text { Number of patients per provider roster. }{ }^{245} \\
\text { Demographics of roster: including age, } \\
\text { morbidity, culture, socioeconomics, and social } \\
\text { and physical environment. }{ }^{246} \\
\\
\text { Average team effectiveness score based on: } \\
\text { - Vision; } \\
\text { - Participative safety; } \\
\text { - Task orientation; and } \\
\text { - Support for innovation. }{ }^{247}\end{array}$ & $\begin{array}{l}\text { Roster is built on agreement } \\
\text { between physician and patient } \\
\text { regarding attachment to each } \\
\text { other. } \\
\text { Consider Canadian Practice-Based } \\
\text { Primary Health Care Survey Tools: } \\
\text { Provider Component, or AlM Team } \\
\text { Effectiveness for team effectiveness } \\
\text { measures. }\end{array}$ \\
\hline
\end{tabular}

${ }^{242}$ This table was developed from critical appraisal of our experiences in the Taber Integrated Primary Care Project, the Chinook Primary Care Network, Hospital Flow and Alberta Aim. The table is intended to generate reflection and discussion on the appropriateness of the measures proposed. The bolded measures are those core initial measures that we recommend be measured related to primary care across the province.

${ }^{243}$ Health Quality Council of Alberta, "Health Quality Matrix," (2005). Ed. Dimensions of Quality (Health Quality Council of Alberta).

${ }^{244}$ http://albertaaim.ca/Resources/Measurement/AIM_Measurement_Overview.pdf: 4 and 5

245 "Program Evaluation Framework,” (2006). Primary Care Initiative Committee. p. 11.

${ }^{246}$ Ibid., p. 18.

247 "Pan-Canadian Primary Health Care Indicator Update Report," (2012). Canadian Institute for Health Information. p. 164.

248 "Healthcare Team Effectiveness Application Guide," (2009). Group Expedia. 


\section{APPENDIX 1: ACCOUNTABILITY FRAMEWORK (cont'd)}

\begin{tabular}{|c|c|c|c|c|}
\hline Objective & $\begin{array}{c}\text { Related } \\
\text { HQCA } \\
\text { Quality } \\
\text { Dimensions }\end{array}$ & \begin{tabular}{|c|} 
Unit \\
of \\
Measure
\end{tabular} & $\begin{array}{l}\text { Indicator/Measure } \\
\text { Recommendations }\end{array}$ & $\begin{array}{l}\text { Rationale/ } \\
\text { Comments }\end{array}$ \\
\hline $\begin{array}{l}\text { PATIENT } \\
\text { ENGAGEMENT } \\
\text { Patients and } \\
\text { families are active } \\
\text { partners in their } \\
\text { care; patients } \\
\text { actively } \\
\text { participate in } \\
\text { decision-making, } \\
\text { quality } \\
\text { improvement and } \\
\text { providing } \\
\text { feedback to } \\
\text { ensure patients' } \\
\text { expectations are } \\
\text { met. }\end{array}$ & Acceptability & $\begin{array}{l}\text { Entire } \\
\text { roster }\end{array}$ & $\begin{array}{l}\text { PATIENT EXPERIENCE: } \\
\text { Percentage of patient population, age } 18 \text { and } \\
\text { older, who reported that the current services } \\
\text { offered by the place they go to for primary } \\
\text { health care (PHC) meet their needs. }{ }^{249} \\
\text { Measure patient experience related to core } \\
\text { attributes of access, continuity, comprehensive } \\
\text { whole-person care, and care coordination. } \\
\text { Per cent of PHC clients / patients, } 18 \text { years and } \\
\text { over, with a chronic condition(s), who actively } \\
\text { participated in the development of a treatment } \\
\text { plan with their PHC provider. }{ }^{250}\end{array}$ & $\begin{array}{l}\text { Consider tools like Primary Care } \\
\text { Assessment Survey; Primary Care } \\
\text { Assessment Tool; Components of } \\
\text { Primary Care Index; Canadian } \\
\text { Survey of Experiences with Primary } \\
\text { Health Care. Build upon the work } \\
\text { done by Haggerty }{ }^{25 I} \text { to measure } \\
\text { the patient experience related to } \\
\text { the core attributes. } \\
\text { Questions/scales should be } \\
\text { reviewed with providers and } \\
\text { patients for fitness for use. Once } \\
\text { core measures/scales have been } \\
\text { decided, support providers to add } \\
\text { additional questions as } \\
\text { circumstances warrant. Alberta } \\
\text { Health will need to support this } \\
\text { form of data collection financially. } \\
\text { This process will take time to } \\
\text { complete, but there is no survey } \\
\text { that captures the patient } \\
\text { perspective on all of the attributes. } \\
\text { We recommend, in the interim, } \\
\text { using part of the Primary Care } \\
\text { Assessment Survey. Specifically, the } \\
32 \text { items under the scales of } \\
\text { accessibility, relational continuity, } \\
\text { interpersonal communication and } \\
\text { respectfulness; these scales have } \\
\text { strong psychometric properties. } \\
\text { 252 }\end{array}$ \\
\hline $\begin{array}{l}\text { The physician is } \\
\text { part of a core } \\
\text { team that } \\
\text { coordinates to } \\
\text { preserve } \\
\text { relational } \\
\text { continuity. Each } \\
\text { patient has an } \\
\text { ongoing } \\
\text { relationship with } \\
\text { the physician } \\
\text { within the team, } \\
\text { and team is } \\
\text { trained to provide } \\
\text { first contact, } \\
\text { continuous and } \\
\text { comprehensive } \\
\text { whole person- } \\
\text { oriented care. }\end{array}$ & $\begin{array}{l}\text { Accessibility; } \\
\text { appropriateness }\end{array}$ & $\begin{array}{l}\text { Entire } \\
\text { roster }\end{array}$ & $\begin{array}{l}\text { See patient engagement as well; } \\
\text { physician continuity. (The calculation is as } \\
\text { follows: Patient visits to the physician *Average } \\
\text { full time hours/ Patient visit to all physicians * } \\
\text { Hours working in office.) }\end{array}$ & $\begin{array}{l}\text { AlM's definition of continuity. } \\
\text { Work with Mark Murray and } \\
\text { Associates, primary care } \\
\text { providers/teams, and HQCA to } \\
\text { develop a meaningful measure of } \\
\text { continuity for teams in addition to } \\
\text { physician continuity measure. }\end{array}$ \\
\hline
\end{tabular}

249 "Pan-Canadian Primary Health Care Indicator Update Report," (2012). op. cit. p. 115.

250 "Pan-Canadian Primary Health Care Indicators," (2006). Canadian Institute of Health Information. p. 41.

${ }^{251}$ Haggerty, Jeannie L. et al.(2011). "Validation of Instruments to Evaluate Primary Healthcare from the Patients' Perspective," Healthcare Policy 7: 13-20.

${ }^{252}$ Haggerty, Jeannie L. (2011).“Measurement of Healthcare Attributes from the Patients' Perspective,” Healthcare Policy 7.

${ }^{253}$ http://albertaaim.ca/Resources/Measurement/AIM_Measurement_Overview.pdf pp.15-16. 


\section{APPENDIX 1: ACCOUNTABILITY FRAMEWORK (cont'd)}

\begin{tabular}{|c|c|c|c|c|}
\hline Objective & $\begin{array}{c}\text { Related } \\
\text { HQCA } \\
\text { Quality } \\
\text { Dimensions } \\
\end{array}$ & \begin{tabular}{|c|} 
Unit \\
of \\
Measure
\end{tabular} & $\begin{array}{l}\text { Indicator/Measure } \\
\text { Recommendations }\end{array}$ & $\begin{array}{l}\text { Rationale/ } \\
\text { Comments }\end{array}$ \\
\hline $\begin{array}{l}\text { COORDINATION } \\
\text { Care is } \\
\text { coordinated and } \\
\text { existing/new } \\
\text { services are } \\
\text { integrated across } \\
\text { all elements of } \\
\text { the complex } \\
\text { health-care } \\
\text { system and } \\
\text { connected to the } \\
\text { primary care hub. }\end{array}$ & $\begin{array}{l}\text { Acceptability; } \\
\text { appropriateness }\end{array}$ & \begin{tabular}{|l|} 
Provincial \\
PHC level \\
\\
\\
Individual \\
practice: \\
Entire \\
roster
\end{tabular} & $\begin{array}{l}\text { See patient engagement as well; } \\
\text { Per cent of PHC organizations who currently } \\
\text { coordinate client/patient care with other } \\
\text { health-care organizations using standardized } \\
\text { clinical protocols or assessment tools. }{ }^{254} \\
\text { Recommend revising the above indicator to } \\
\text { practice level. } \\
\text { - Collaboration/tool integration between PHC } \\
\text { and other health-care sectors for top three } \\
\text { chronic conditions and for top five per cent } \\
\text { highest health-care system users on their } \\
\text { roster. This could be determined via random } \\
\text { chart audits. } \\
\text { - Per cent of PHC clients/patients, } 18 \text { years } \\
\text { and over, who felt that unnecessary medical } \\
\text { tests were ordered because the test had } \\
\text { already been done over the past } 12 \text { months. }\end{array}$ & $\begin{array}{l}\text { There needs to be linkages or even } \\
\text { co-location between services in a } \\
\text { community or zone versus } \\
\text { duplication of these services within a } \\
\text { clinic. Specific measures are needed } \\
\text { to ensure best use of resources and } \\
\text { integration of services. System } \\
\text { redesign of services is key and AHS } \\
\text { must realign services to support } \\
\text { primary care to meet the needs of } \\
\text { the roster/community. Consider } \\
\text { measures of cost, efficiency, and } \\
\text { team related to these aspects of } \\
\text { coordination. Tool and care plan } \\
\text { development templates should be } \\
\text { consistent across diseases and } \\
\text { across populations. }\end{array}$ \\
\hline $\begin{array}{l}\text { COMPREHENSIVE- } \\
\text { NESS } \\
\text { The core team is } \\
\text { responsible for } \\
\text { providing } \\
\text { comprehensive, } \\
\text { whole-person } \\
\text { care, or arranging } \\
\text { needed care with } \\
\text { other qualified } \\
\text { professionals } \\
\text { across the } \\
\text { system. }\end{array}$ & $\begin{array}{l}\text { Efficiency; } \\
\text { acceptability }\end{array}$ & $\begin{array}{l}\text { Entire } \\
\text { roster }\end{array}$ & $\begin{array}{l}\text { Age-standardized acute care hospitalization rate } \\
\text { for conditions where appropriate ambulatory } \\
\text { care may prevent or reduce the need for } \\
\text { admission to hospital (Asthma, Congestive } \\
\text { Heart Failure (CHF), Myocardial Infarction (MI), } \\
\text { Chronic Obstructive Pulmonary Disease (COPD), } \\
\text { Hypertension, Angina, Diabetes). }{ }^{256} \\
\\
\text { Per cent of rostered population who visited an } \\
\text { emergency department for treatment of } \\
\text { Asthma, Congestive Heart Failure, COPD, } \\
\text { Hypertension, Angina, Diabetes, Anxiety, } \\
\text { Depression. } \\
\\
\text { PREVENTION MEASURES } \\
\text { Percentage of female patient population, age } \\
50 \text { to } 74, \text { who had a mammogram ordered; } \\
\\
\text { Percentage of patient population, age } 50 \text { to } \\
74, \text { who had a screening test ordered for colon } \\
\text { cancer; }{ }^{259}\end{array}$ & $\begin{array}{l}\text { A link to rosters helps indicate if there } \\
\text { is an impact on emergency room and } \\
\text { hospitalization rates when core } \\
\text { attributes are addressed well } \\
\text { (efficiency). This doesn't mean just } \\
\text { saving money, but also increasing } \\
\text { capacity. } \\
\text { These rates should be linked to } \\
\text { patient rosters (ER and } \\
\text { hospitalization). Indicators should be } \\
\text { selected based on roster needs and } \\
\text { characteristics. Some core measures, } \\
\text { i.e., for prevention and chronic } \\
\text { disease management should be } \\
\text { established across the province for all } \\
\text { to report on (those included here for } \\
\text { example) and others should be } \\
\text { chosen based on population served. } \\
\text { The measures should be the same, } \\
\text { however, across the province related } \\
\text { to a specific chronic disease or } \\
\text { prevention; i.e., if a team in the north } \\
\text { is measuring effectiveness of their } \\
\text { care for individuals with congestive } \\
\text { heart failure they are using the same } \\
\text { indicators as a team from the south. } \\
\text { The PanCanadian Primary Health Care } \\
\text { Indicator Update Report (2012) } \\
\text { provides measures that can be used. } \\
\text { A few examples of CIHI measures are } \\
\text { included under the chronic disease } \\
\text { measures heading in the Indicator/ } \\
\text { Measure Recommendations column. }\end{array}$ \\
\hline
\end{tabular}

\footnotetext{
254 "Pan-Canadian Primary Health Care Indicators," (2006) op. cit. p. 120.

${ }^{255}$ Ibid., p. 123.

256 "Pan-Canadian Primary Health Care Indicator Update Report," (2012) op. cit. p. 75.

${ }^{257}$ Ibid., p. 79

${ }^{258}$ Ibid., p. 125.

${ }^{259}$ Ibid., p. 122.
} 


\section{APPENDIX 1: ACCOUNTABILITY FRAMEWORK (cont'd)}

\begin{tabular}{|c|c|c|c|c|}
\hline Objective & $\begin{array}{c}\text { Related } \\
\text { HQCA } \\
\text { Quality } \\
\text { Dimensions }\end{array}$ & $\begin{array}{c}\text { Unit } \\
\text { of } \\
\text { Measure }\end{array}$ & $\begin{array}{l}\text { Indicator/Measure } \\
\text { Recommendations }\end{array}$ & $\begin{array}{l}\text { Rationale/ } \\
\text { Comments }\end{array}$ \\
\hline & Acceptability & $\begin{array}{l}\text { Entire } \\
\text { roster }\end{array}$ & $\begin{array}{l}\text { CHRONIC DISEASE MEASURES: } \\
\text { Percentage of patient population, age } 18 \text { and } \\
\text { older, with diabetes mellitus who received } \\
\text { testing for all of the following: Hemoglobin A1c } \\
\text { (HbA1c); Full fasting lipid profile screening;; } \\
\text { Nephropathy screening; Foot examination; } \\
\text { Blood pressure measurement; and } \\
\text { Obesity/overweight screening; } \\
\text { Per cent of patients with HbA1c < 7\%, LDL < } \\
100 \mathrm{mg} / \mathrm{dl} \text {, } \\
\text { Percentage of patient population, age } 18 \text { and } \\
\text { older, with hypertension for a duration of at } \\
\text { least } 12 \text { months, who have blood pressure } \\
\text { measurement control. } \\
\text { Number of services provided to roster by type } \\
\text { of service (e.g., rehabilitative services, psycho- } \\
\text { social services. }\end{array}$ & $\begin{array}{l}\text { According to Haggerty et al }{ }^{263} \text { the } \\
\text { range of services provided is } \\
\text { probably best assessed by } \\
\text { providers. }\end{array}$ \\
\hline
\end{tabular}

\footnotetext{
${ }^{260}$ Ibid., p. 145.

${ }^{261}$ Ibid., p. 80.

${ }^{262}$ Ibid., p. 68.

${ }^{263}$ Haggerty (2011) op. cit. p. 15.
} 


\section{APPENDIX 2: REMUNERATION IN THREE MODELS OF ONTARIO PRIMARY CARE ${ }^{264,265}$}

\begin{tabular}{|c|c|}
\hline Type of Alternate Payment Approach & How Physicians Are Paid \\
\hline $\begin{array}{l}\text { Family Health Group (FHG) } \\
\text { Introduced in } 2003 \\
\text { The only formal primary care model that has the majority } \\
\text { of physician reimbursement through FFS. These are not } \\
\text { considered Family Health Teams (FHTs). The FHT model } \\
\text { adds multidisciplinary clinicians to the other models } \\
\text { (below). } \\
\text { - Three or more physicians practicing together - not } \\
\text { necessarily in the same office space but in close } \\
\text { proximity. } \\
\text { - Patient enrolment is strongly encouraged. } \\
\text { - Regular office hours and three to five sessions of } \\
\text { extended hours (weekday evenings and/or weekends) } \\
\text { based on number of group physicians. Patient volume } \\
\text { may require additional sessions. Each after-hours } \\
\text { session must be a minimum of three hours in duration. } \\
\text { - Nurse-staffed, after-hours Telephone Health Advisory } \\
\text { Service provides advice to enrolled patients. } \\
\text { - Physicians must sign agreement to join. }\end{array}$ & $\begin{array}{l}\text { Enhanced FFS and incentives for ministry-assigned patients and } \\
\text { enrolled patients, as well as comprehensive care capitation } \\
\text { payments for enrolled patients. } \\
\text { Enhanced FFS is } 110 \text { per cent of the traditional FFS amount. } \\
\text { Physicians also receive additional payments, including: } \\
\text { - Complex capitation payments for hard-to-care-for patients. } \\
\text { - Incentive payments for services such as preventive care, diabetes } \\
\text { management, after-hours services, and enrolling unattached } \\
\text { patients. } \\
\text { - Payments for being on-call to provide after-hours telephone health } \\
\text { advice to enrolled patients. }\end{array}$ \\
\hline $\begin{array}{l}\text { Family Health Network (FHN) } \\
\text { Introduced in } 2001\end{array}$ & $\begin{array}{l}\text { Base and comprehensive care capitation, shadow billing, and } \\
\text { incentives for enrolled patients. } \\
\text { Base capitation payment covers } 56 \text { listed services. The base } \\
\text { capitation rate is lower than for Family Health Organizations, because } \\
\text { fewer services are listed. Shadow billing is paid at } 10 \text { per cent of the } \\
\text { traditional FFS value. } \\
\text { As with Family Health Organizations, physicians also receive } \\
\text { additional payments, including: } \\
\text { - FFS payments for any service not listed in the contract and for all } \\
\text { services provided to non-enrolled patients. } \\
\text { - Incentive payments for services such as preventive care, diabetes } \\
\text { management, after-hours services, and enrolling unattached } \\
\text { patients. } \\
\text { - Complex capitation payments for hard-to-care-for patients. } \\
\text { - Payments for being on-call to provide after-hours telephone health } \\
\text { advice to enrolled patients. } \\
\text { - } \$ 5,000 \text { to } \$ 11,000 \text { per year if they work in rural communities. } \\
\text { - Funding of } \$ 12,500 \text { to } \$ 25,000 \text { per year is provided to practices } \\
\text { with at least five physicians to hire an office administrator. }\end{array}$ \\
\hline
\end{tabular}

264 "Funding Alternatives for Family Physicians," (2012). Ministry of Health and Long-Term Care.

${ }^{265}$ Glazier, Richard, Brandon M. Zagorshki, and Jennifer Rayner (2010). "Comparison of Primary Care Models in Ontario by Demographics, Case Mix and Emergency Department Use, 2008/09 to 2009/10. ICES Investigative Report." 


\section{APPENDIX 2: REMUNERATION IN THREE MODELS OF ONTARIO PRIMARY CARE (cont'd)}

\begin{tabular}{|c|c|}
\hline Type of Alternate Payment Approach & How Physicians Are Paid \\
\hline $\begin{array}{l}\text { Family Health Organization (FHO) } \\
\text { Introduced in } 2006 \\
\text { - Three or more physicians work together as a group - not } \\
\text { necessarily in the same office space but in close } \\
\text { proximity. } \\
\text { - Physicians commit to enroll patients. } \\
\text { - Regular office hours and three to five sessions of } \\
\text { extended hours (weekday evenings and/or weekends) } \\
\text { based on number of physicians. Patient volume may } \\
\text { require additional sessions. Each after-hours session } \\
\text { must be a minimum of three hours in duration. } \\
\text { - Nurse-staffed, after-hours Telephone Health Advisory } \\
\text { Service provides advice to enrolled patients. } \\
\text { - Sign governance and Family Health Organization } \\
\text { agreements to join. } \\
\text { - Family Health Organizations can apply to the Ministry of } \\
\text { Health and Long-Term Care for funding to add allied } \\
\text { health professionals if they are successful in their } \\
\text { application for a Family Health Team. }\end{array}$ & $\begin{array}{l}\text { Base and comprehensive care capitation, shadow billing, and } \\
\text { incentives for enrolled patients. } \\
\text { Base capitation payment covers } 118 \text { listed services. Shadow billing } \\
\text { is paid at } 10 \text { per cent of the traditional FFS value. } \\
\text { Physicians also receive additional payments, including: } \\
\text { - FFS payments for any service not listed in the contract and for all } \\
\text { services provided to non-enrolled patients. } \\
\text { - Incentive payments for services such as preventive care, diabetes } \\
\text { management, after-hours services, and enrolling unattached } \\
\text { patients. } \\
\text { - Complex capitation payments for hard-to-care-for patients. } \\
\text { - Payments for being on call to provide after-hours telephone health } \\
\text { advice to enrolled patients. } \\
\text { - } \$ 5,000 \text { to } \$ 11,000 \text { per year if they work in rural communities. } \\
\text { - Funding of } \$ 12,500 \text { to } \$ 25,000 \text { per year is provided to practices } \\
\text { with at least five physicians to hire an office administrator. }\end{array}$ \\
\hline
\end{tabular}




\section{ABOUT THIS PUBLICATION}

The School of Public Policy Research Papers provide in-depth, evidence-based assessments and recommendations on a range of public policy issues. Research Papers are put through a stringent peer review process prior to being made available to academics, policy makers, the media and the public at large. Views expressed in The School of Public Policy Research Papers are the opinions of the author(s) and do not necessarily represent the view of The School of Public Policy.

\section{OUR MANDATE}

The University of Calgary is home to scholars in 16 faculties (offering more than 80 academic programs) and 36 Research Institutes and Centres including The School of Public Policy. Under the direction of Jack Mintz, Palmer Chair in Public Policy, and supported by more than 100 academics and researchers, the work of The School of Public Policy and its students contributes to a more meaningful and informed public debate on fiscal, social, energy, environmental and international issues to improve Canada's and Alberta's economic and social performance.

The School of Public Policy achieves its objectives through fostering ongoing partnerships with federal, provincial, state and municipal governments, industry associations, NGOs, and leading academic institutions internationally. Foreign Investment Advisory Committee of the World Bank, International Monetary Fund, Finance Canada, Department of Foreign Affairs and International Trade Canada, and Government of Alberta, are just some of the partners already engaged with the School's activities.

For those in government, The School of Public Policy helps to build capacity and assists in the training of public servants through degree and non-degree programs that are critical for an effective public service in Canada. For those outside of the public sector, its programs enhance the effectiveness of public policy, providing a better understanding of the objectives and limitations faced by governments in the application of legislation.

\section{DISTRIBUTION}

Our publications are available online at www.policyschool.ca.

\section{DISCLAIMER}

The opinions expressed in these publications are the authors' alone and therefore do not necessarily reflect the opinions of the supporters, staff, or boards of The School of Public Policy.

\section{COPYRIGHT}

Copyright (c) 2013 by The School of Public Policy.

All rights reserved. No part of this publication may be reproduced in any manner whatsoever without written permission except in the case of brief passages quoted in critical articles and reviews.

\section{ISSN}

1919-112x SPP Research Papers (Print)

1919-1138 SPP Research Papers (Online)

\section{DATE OF ISSUE}

September 2013

\section{MEDIA INQUIRIES AND INFORMATION}

For media inquiries, please contact Morten Paulsen at 403-453-0062.

Our web site, www.policyschool.ca, contains more information about The School's events, publications, and staff.

\section{DEVELOPMENT}

For information about contributing to The School of Public Policy, please contact Courtney Murphy by telephone at 403-210-7201 or by e-mail at cdmurphy@ucalgary.ca. 


\section{RECENT PUBLICATIONS BY THE SCHOOL OF PUBLIC POLICY}

THE CANADIAN MANUFACTURING SECTOR, 2002-2008: WHY IS IT CALLED DUTCH DISEASE?

http:/ / policyschool.ucalgary.ca/ ?q=content/ canadian-manufacturing-sector-2002-2008-why-it-called-dutchdisease

Stephen Gordon | September 2013

REDISTRIBUTION OF INCOME: POLICY DIRECTIONS

http:/ / policyschool.ucalgary.ca/ ?q=content/redistribution-income-policy-directions

James Davies | August 2013

INCOME INEQUALITY AND INCOME TAXATION IN CANADA: TRENDS IN THE CENSUS 1980-2005

http:/ / policyschool.ucalgary.ca/?q=content/income-inequality-and-income-taxation-canada-trends-census1980-2005

Kevin Milligan | August 2013

INCOME INEQUALITY, REDISTRIBUTION AND ECONOMIC GROWTH http:/ / policyschool.ucalgary.ca/?q=content/income-inequality-redistribution-and-economic-growth Bev Dahlby and Ergete Ferede | August 2013

DIPLOMACY, GLOBALIZATION AND HETEROPOLARITY: THE CHALLENGE OF ADAPTATION http:/ / policyschool.ucalgary.ca/?q=content/ diplomacy-globalization-and-heteropolarity-challenge-adaptation Daryl Copeland | August 2013

UNHEALTHY PRESSURE: HOW PHYSICIAN PAY DEMANDS PUT THE SQUEEZE ON PROVINCIAL HEALTH-CARE BUDGETS

http:/ / policyschool.ucalgary.ca/ ?q=content/ unhealthy-pressure-how-physician-pay-demands-put-squeezeprovincial-health-care-budgets

Hugh M. Grant and Jeremiah Hurley | July 2013

TRENDS, PEAKS, AND TROUGHS: NATIONAL AND REGIONAL EMPLOYMENT CYCLES IN CANADA http:// policyschool.ucalgary.ca/?q=content/trends-peaks-and-troughs-national-and-regional-employmentcycles-canada Ronald Kneebone and Margarita Gres | July 2013

THE FISCAL, SOCIAL AND ECONOMIC DIVIDENDS OF FEELING BETTER AND LIVING LONGER http:/ / policyschool.ucalgary.ca/?q=content/ fiscal-social-and-economic-dividends-feeling-better-and-living-longer J.C. Herbert Emery, Ken Fyie, Ludovic Brunel and Daniel J. Dutton | June 2013

CHINA'S STATE-OWNED ENTERPRISES: HOW MUCH DO WE KNOW? FROM CNOOC TO ITS SIBLINGS http:/ / policyschool.ucalgary.ca/ ?q=content/ chinas-state-owned-enterprises-how-much-do-we-know-cnooc-itssiblings

Duanjie Chen | June 2013

POLICY OPTIONS FOR REDUCING DIETARY SODIUM INTAKE

http:/ / policyschool.ucalgary.ca/ ?q=content/ policy-options-reducing-dietary-sodium-intake.pdf Lindsay McLaren | June 2012 